\title{
Variability of Chemical Properties of the Atmospheric Aerosol above Lake Baikal during Large Wildfires in Siberia
}

\author{
Liudmila Golobokova *(D), Tamara Khodzher, Olga Khuriganova, Irina Marinayte, \\ Natalia Onishchuk, Polina Rusanova and Vladimir Potemkin \\ Limnological Institute, Siberian Branch of the Russian Academy of Sciences, 664033 Irkutsk, Russia; \\ khodzher@lin.irk.ru (T.K.); khuriganowa@mail.ru (O.K.); marin@lin.irk.ru (I.M.); onischuk@lin.irk.ru (N.O.); \\ babushok_pa@mail.ru (P.R.); klimat@mail.ru (V.P.) \\ * Correspondence: lg@lin.irk.ru
}

Received: 14 October 2020; Accepted: 12 November 2020; Published: 14 November 2020

\begin{abstract}
The article analyzes the chemical composition (ions, elements, and polycyclic aromatic hydrocarbons) of the atmospheric aerosol in the near-water layer of the atmosphere above Lake Baikal during wildfires in Siberia. Aerosol deposition affects the aquatic environment of the watershed basin and the lake itself. The current law on Lake Baikal limits the activity of the permanent stationary anthropogenic sources of the aerosol in the central ecological zone, and they do not have a significant negative impact. Wildfires can have a much greater impact on the environment. Smoke emissions entering the area of Lake Baikal due to wildfires change the chemical properties of the atmospheric aerosol and increase its mass and number concentration. The concentrations of $\mathrm{NH}_{4}{ }^{+}, \mathrm{K}^{+}, \mathrm{NO}_{3}{ }^{-}$, and $\mathrm{SO}_{4}{ }^{2-}$, which enter with submicron aerosol fraction, increase in the ionic composition of the aerosol. The composition of polyaromatic compounds changes, and their concentrations increase. Elevated concentrations of $\mathrm{B}, \mathrm{Mn}, \mathrm{Zn}, \mathrm{As}, \mathrm{Sr}, \mathrm{Cd}$, and $\mathrm{Pb}$ in the composition of aerosol indicate the influx of air masses from the areas prone to wildfires. Despite the sporadic effects of these natural factors, they affect the pollution of various Baikal ecosystems, especially small tributaries of the lake, whose main supply is atmospheric.
\end{abstract}

Keywords: aerosol; Baikal; elements; ions; mass and number concentrations of aerosol; polycyclic aromatic hydrocarbons; wildfires

\section{Introduction}

The problem of air pollution has become extremely serious and acute in recent decades, and is an increasing concern for people. The impact of pollutants in the air on the human body and environment is the main criterion for establishing standards to assess air quality. It is widely recognized and scientifically substantiated that approximately $60 \%$ of all emissions are the anthropogenic air pollution $[1,2]$. Much attention is currently paid to the negative impact of anthropogenic pollution on human health [3,4]. The aerosol of urbanized areas is one of the main constituents of the anthropogenic aerosol. The article by [5] provides a modern overview of environmental solid particle pollution from various sources in certain regions of the world. Transport, industry, and biomass combustion in lowand middle-income countries are important contributors to the formation of fine particles in cities. Such studies are relevant to the integration of information about the distribution of emission sources. Prioritizing solutions that can reduce air emissions will complete the progress pattern towards a healthier and more sustainable environment. However, not only anthropogenic but also natural sources negatively affect the state of the air. Dust storms are a serious and increasing environmental problem. 
Dust plays an important role in the climate system, affecting radiation balance [6], biogeochemical cycles [7], air quality, and human health [8]. Due to climate change, dust is becoming one of the main sources of air pollution in the atmosphere of the Northern Hemisphere. For example, in recent decades, dust storms have been increasing in China and Mongolia [9-11]. Dust storms are so powerful that during five-seven days, dust travelling through the Korean Peninsula, the islands of Japan and the Pacific Ocean can reach the shores of North America [12].

Wildfires also play an important role in air pollution, the number of which is increasing every year [13]. Climate change characterized by long-term droughts contributes to their spread in various regions of the planet $[14,15]$. Wildfires destroy large forest areas, which threatens disruption of the ecological stability of natural ecosystems. Wildfires also pollute air, soils, surface and ground waters, and cause a significant decrease in biodiversity. Atmospheric emissions of various harmful substances of the burnt material and $\mathrm{CO}_{2}$ from large fires, as well as large areas of burnt forests, accelerate the global warming of the planet. Soot is one of the indicators of air pollution by combustion products, which is a factor affecting not only the climate but also human health [16-19]. International statistics on wildfires distinguishes some regions that are most prone to this event. These is the USA, Canada, Portugal, France, Spain, Brazil, Australia, and Russia [2].

In Russia, Siberia and the Far East are the most fire-prone regions. According to the Avialesokhrana monitoring department, in Russia, the area of fires in 2018 was 8 million 674 thousand hectares (2.5 times greater than in 2017). In 2019, wildfires in Siberia were record-breaking over recent years, occurring in remote areas in the north of the Krasnoyarsk Territory, the Irkutsk Oblast, the Republic of Sakha (Yakutia), and the Transbaikal Territory and amounting to ca. 15 million hectares [20]. They are among the world's most severe wildfires which have occurred over the past 10 years [21].

Lake Baikal is the main orographic unit of Siberia. Lake Baikal is the world's largest freshwater lake located in the center of the Asian part of Russia, stretching from the southwest to the northeast for $636 \mathrm{~km}$. The width of the lake ranges from 25 to $80 \mathrm{~km}$. Mountain ranges surround its basin. On the west coast, their height is from $1000 \mathrm{~m}$ in the southern part of the lake to $1600-1700 \mathrm{~m}$ in the central part and above $2000 \mathrm{~m}$ in its northern part. The east coast in the northern part of the lake is limited by ridges with a maximum height of up to $2840 \mathrm{~m}$, which are replaced by low-mountain blocks with heights of 900-1000 m. The southern part of the east coast of Lake Baikal is limited by the Khamar-Daban Ridge with the highest point above $2300 \mathrm{~m}$. In the zones of the intermountain junctions of Baikal mountain ranges, there are areas with lowered landforms, which are occupied with plains and large river valleys. The northern margin of Lake Baikal represents vast deltas of the Upper Angara and Kichera rivers. The area of the Selenga River delta is the largest gap in the mountainous margin of the east coast of Lake Baikal. The only river flowing from Lake Baikal, the Angara River, is located in the southwestern part of Lake Baikal. In morphological terms, the Baikal depression has three individual basins: southern, central, and northern. The basins are clearly defined by the steepness of the supra-aquatic slopes [22].

High-mountain areas have a great impact on the moving air and dynamics of seasonal baric formations. The southern part of East Siberia, where Lake Baikal is located, due to its considerable distance from oceans and seas, has a sharply continental climate with long cold winters and relatively warm summers. During the warm seasons, cyclonic activity intensifies with the influx of continental and Atlantic air masses from the west. Continental Central Asian dry and warm air currents come from the south and south-west. In the second half of the summer, southern cyclones activate, bringing humid air masses through Northern Mongolia [22].

By the decision of the 20th session of the UNESCO World Heritage Committee of 5 December 1996, Lake Baikal was included in the natural World Heritage List. The influx of substances from the atmosphere with the aerosol during dry deposition and with precipitation can have a substantial effect on various ecosystems of the lake basin, including the formation of the water composition in the Baikal tributaries, as shown in [23]. To protect the unique ecological system of the lake, ecological control over the state of its natural environment is carried out. At present, climate warming in the Baikal 
region is faster than in other Russian regions, which leads to a decrease in the amount of precipitation, moistening of the area and water runoff of the rivers flowing into the lake [24]. With these changes, there is an increase in the number of wildfires at the local level near the lake coast. Thus, during wildfires in 2015, 2016, and 2019 in the south (the Bolshoye Goloustnoye area and Peschanaya Bay), the centre (Olkhon Island), and the north (Elokhin Cape, Davsha, and Sosnovka Bay), hundreds of hectares of various steppe and forest landscapes burned out.

This study aims to show the effect of wildfires on the state of the atmosphere in one of the world's cleanest places, Lake Baikal. The results of aerosol investigations above the water area of Lake Baikal, which were carried out in 2019, involving the data on previous years, were source material for the analysis. This research is important for assessing the influx of substances from the atmosphere with aerosol particles during dry deposition and with precipitation involved in the formation of the water composition in Lake Baikal and its watershed basin.

\section{Materials and Methods}

Comprehensive studies of the spatiotemporal distribution of aerosol impurities in the near-water atmospheric layer above Lake Baikal were carried out from 24 July to 4 August 2019 onboard the research vessel (RV) «Akademik V.A. Koptyug» (Figure 1A). Figure 1B shows the RV route in the cruise and sites of the main stops. The total length of the route was $\sim 1700 \mathrm{~km}$. From 24 to $25 \mathrm{July}$, research was under way into the atmosphere in Southern Baikal with a stop in the Baikalsk town on the east coast of Southern Baikal. From 25 to 28 July, the RV route was along the west coast towards the north with a stop near Elokhin cape. From 27 to 28 July, the RV was in the northern margin of the lake with moorings in the Severobaikalsk town and the Nizhneangarsk settlement. When the RV was under way in the opposite direction along the east coast from 29 July to 2 August, it stopped in Chivyrkuy Bay and Barguzin Bay, near the Turka settlement and delta of the Selenga River. Then, the RV followed on Southern Baikal to the Listvyanka settlement with a stop in the Bolshiye Koty settlement.

Aerosol samples were taken using a high volume sampler (Andersen Instrument Inc., New York, NY, USA) on the Whatman-41filters with a size of $203 \times 254 \mathrm{~mm}$ and a flow rate of 250-300 L/min. To exclude the influence of exhaust gases and aerosol emission of the RV engine, the sampler was installed on the upper deck, at a height of ca. $9 \mathrm{~m}$ above the water surface (see Figure 1A). An acoustic meteorological complex owned by the center of shared facilities «Atmosphere» (V.E. Zuev Institute of Atmospheric Optics, Siberian Branch of the Russian Academy of Sciences) was also installed there.
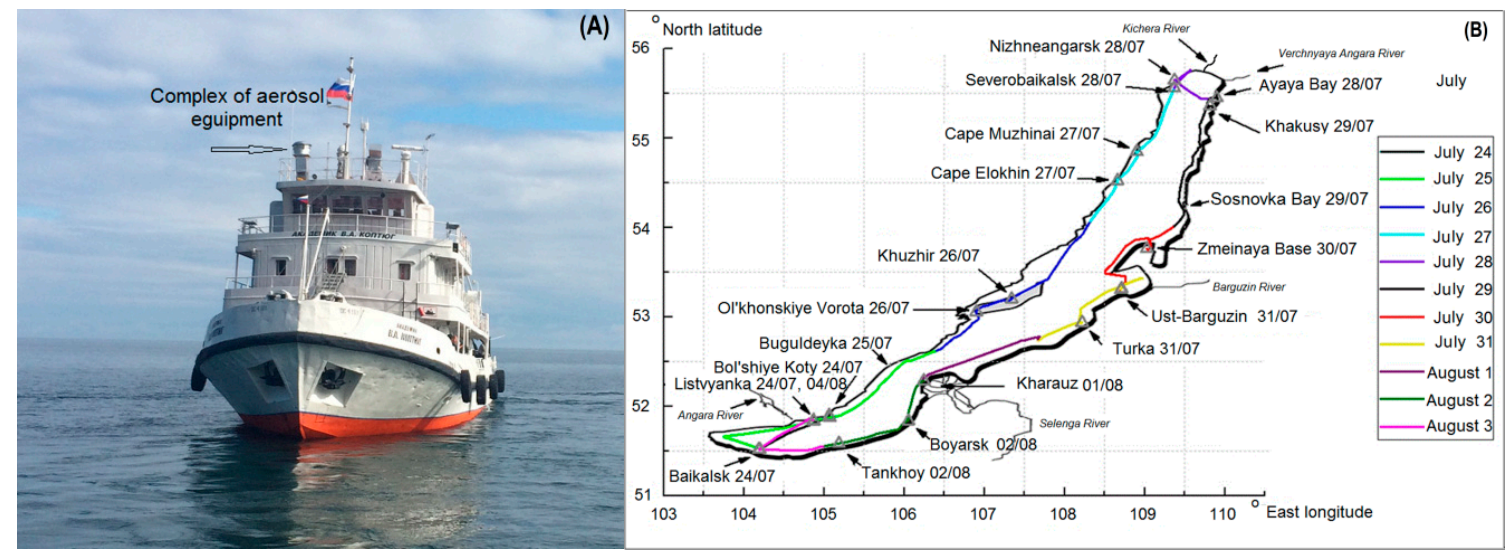

Figure 1. The research vessel (RV) «Akademik V.A. Koptyug» (A) and scheme of the RV route (B), sites of the main stops.

The chemical composition of the aerosol was studied using high-tech equipment that meets generally accepted world standards. To determine ions, the impurities were extracted with deionized water in an ultrasonic bath for $30 \mathrm{~min}$. The solutions were filtered through cellulose 
acetate membrane filters with a pore size of $0.2 \mu \mathrm{m}$. The concentrations of the $\mathrm{Na}^{+}, \mathrm{K}^{+}, \mathrm{Mg}^{2+}$, $\mathrm{Ca}^{2+}$, and $\mathrm{NH}_{4}{ }^{+}$cations, as well as $\mathrm{Cl}^{-}, \mathrm{NO}_{3}{ }^{-}, \mathrm{Br}^{-}$, and $\mathrm{SO}_{4}{ }^{2-}$ anions, were measured in the filtrate using the ICS-3000 Ion Chromatography System (Dionex Corporation, Sunnyvale, California, USA) with an accuracy of 2-6\%. Li, Be, B, Al, Ti, V, Cr, Mn, Fe, Co, Ni, Cu, Zn, As, Se, Sr, $\mathrm{Mo}, \mathrm{Ag}, \mathrm{Cd}, \mathrm{Sn}, \mathrm{Sb}, \mathrm{Ba}, \mathrm{W}, \mathrm{Pb}, \mathrm{U}$, and $\mathrm{Tl}$ were analyzed by inductively coupled plasma mass spectrometry on an Agilent 7500ce mass spectrometer (USA). To prepare samples for analysis, we used the technique proposed in [25]. It involved the extraction of the impurities collected on the filter with concentrated nitric acid. The concentrations of 18 polyaromatic hydrocarbons (PAHs): naphthalene, acenaphthylene, acenaphthene, fluorene, phenanthrene, anthracene, fluoranthene, pyrene, benzo[a]anthracene, chrysene, benzo[b]fluoranthene, benzo[k]fluoranthene Benzo[e]pyrene, benzo[a]pyrene, perylene, indeno $[1,2,3-\mathrm{c}, \mathrm{d}]$ pyrene, and benzo[g,h,i]perylene, dibenzo[a,h]anthracene, in aerosol were measured by the method of internal standards with the addition of phenathrene-d10, chrysene-d12 and perylene-d12 solutions [26]. The prepared samples were analyzed on an Agilent, GC System 7890B, 7000 CGC/MSTripleQuad gas chromatography-mass spectrometer (Agilent Scientific Instruments, Santa Clara, CA, USA).

The quality of analyses has been repeatedly confirmed by the participation in the interlaboratory intercalibrations according to international programs under the auspices of the World Meteorological Organization (WMO) andAcid Deposition Monitoring Network in East Asia (EANET), which was included in the annual reports of WMO [27] and EANET [28].

To study the total number concentration and the distribution of particles by sizes of the microdisperse aerosol fraction, a Handheld 3016 IAQ particle counter (Lighthouse, Fremont, California, USA) was used, which can count particles through six channels $(>0.3,>0.5,>1,>2.5,>5$, and $>10 \mu \mathrm{m})$ and display the differential particle count data. Air was pumped with an internal pump at a speed of $2.8 \mathrm{~L} / \mathrm{min}$. The measurement accuracy was $5 \%$. Measurements were carried out every hour along the $\mathrm{RV}$ route.

To determine aerosol sources, three-day back trajectories of air masses arriving from heights of 500, 1000, and $1500 \mathrm{~m}$ were analyzed. The data from the National Oceanic and Atmospheric Administration of the United States based on the HYSPLIT model (Version 2) were used as the source information [29]. The results of the 2019 study were compared with our data obtained in the spring (June) and summer (July-August) observation periods of past years [30-32].

\section{Results and Discussion}

3.1. Spatial Distribution of Average Physicochemical Characteristics of the Aerosol above Lake Baikal Based on the Results of Long-Term Studies

According to the data from Arctic and Antarctic Research Institute [33], from 24 to 27 July 2019, the Baikal region was under the influence of the cyclone that came from the northwest, with low clouds and rainy weather at times; the rains cleared the atmosphere. On $23 \mathrm{July}$, satellite monitoring recorded a wildfire on the east coast of Lake Baikal near Sosnovka Bay, the smoke of which spread over the water area of Northern Baikal. From 26 July to 1 August, many fire sites were recorded north of Lake Baikal (Figure 2) [29]. During the expedition, the total area of wildfires in Siberia reached 3 million ha [20], the smog from which was recorded in the atmosphere above the entire water area of the lake. It has been shown many times that the emission of combustion products (gases, soot, and aerosol) into the atmosphere negatively affects not only the quality but also its optical and microphysical properties [34].

For the determination of the influence of different sources on the formation of the atmospheric aerosol above the lake, we constructed back trajectories of air mass transport for each day of the expedition from 24 July to 4 August 2019 (Figure 3) [29]. An analysis of back trajectories revealed that the smoke from the wildfire from 25 to 27 July near Sosnovka Bay spread over the lake from the southeast to the northwest. From 28 July to 1 August, air masses came to the lake from the northern areas of the Irkutsk Region and southern areas of Yakutia were engulfed in wildfires, the smoke 
emission from which spread over Northern and Central Baikal. From 2 to 3 August, the directions of air currents changed; clean air from Mongolia filled the southern basin of Lake Baikal.
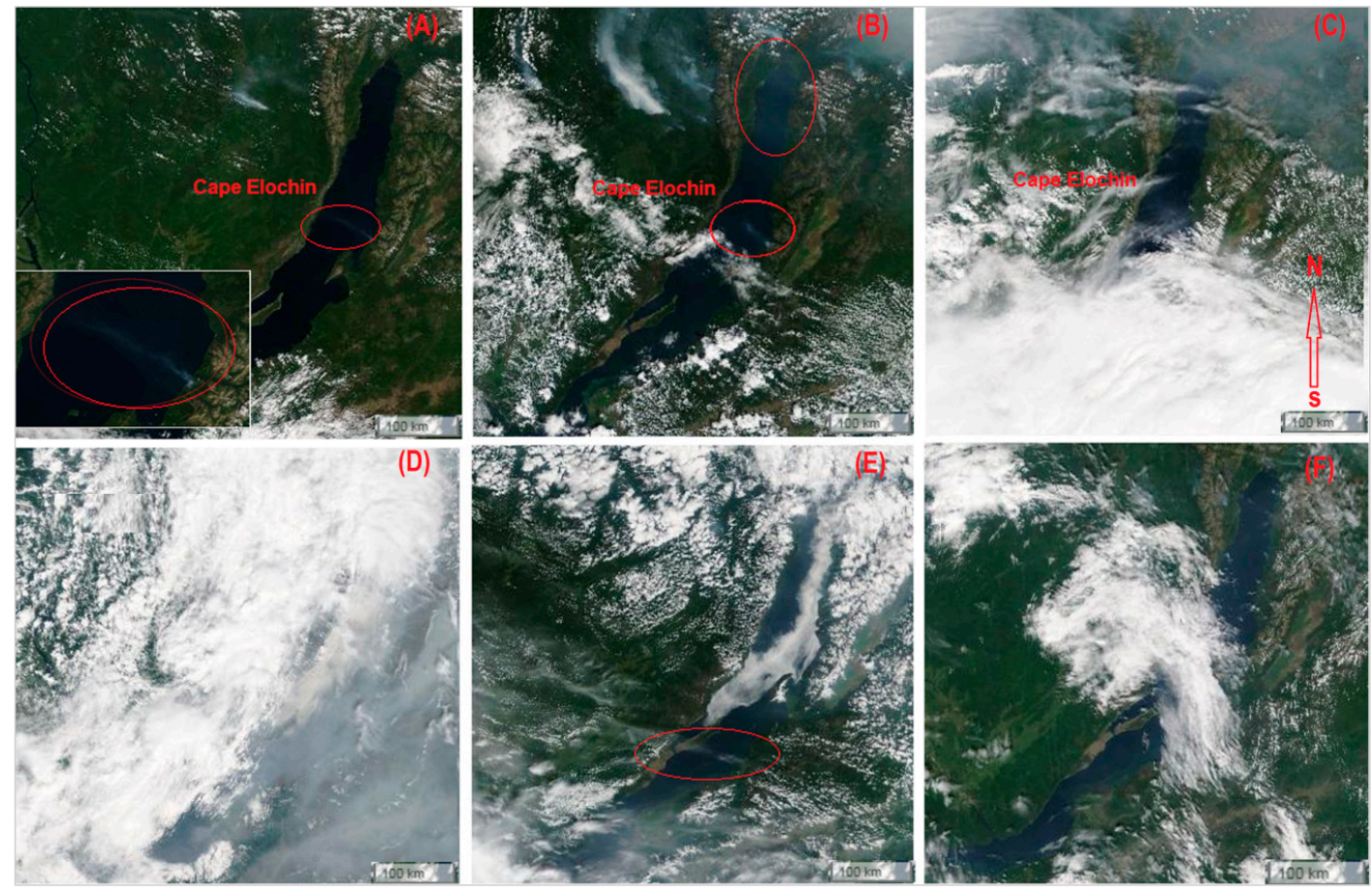

Figure 2. Satellite images of Lake Baikal with smoke plumes from wildfires: (A) - 25 July, (B) - 26 July, (C) -27 July, (D) -1 August, (E) -2 August, (F)—3 August [29].
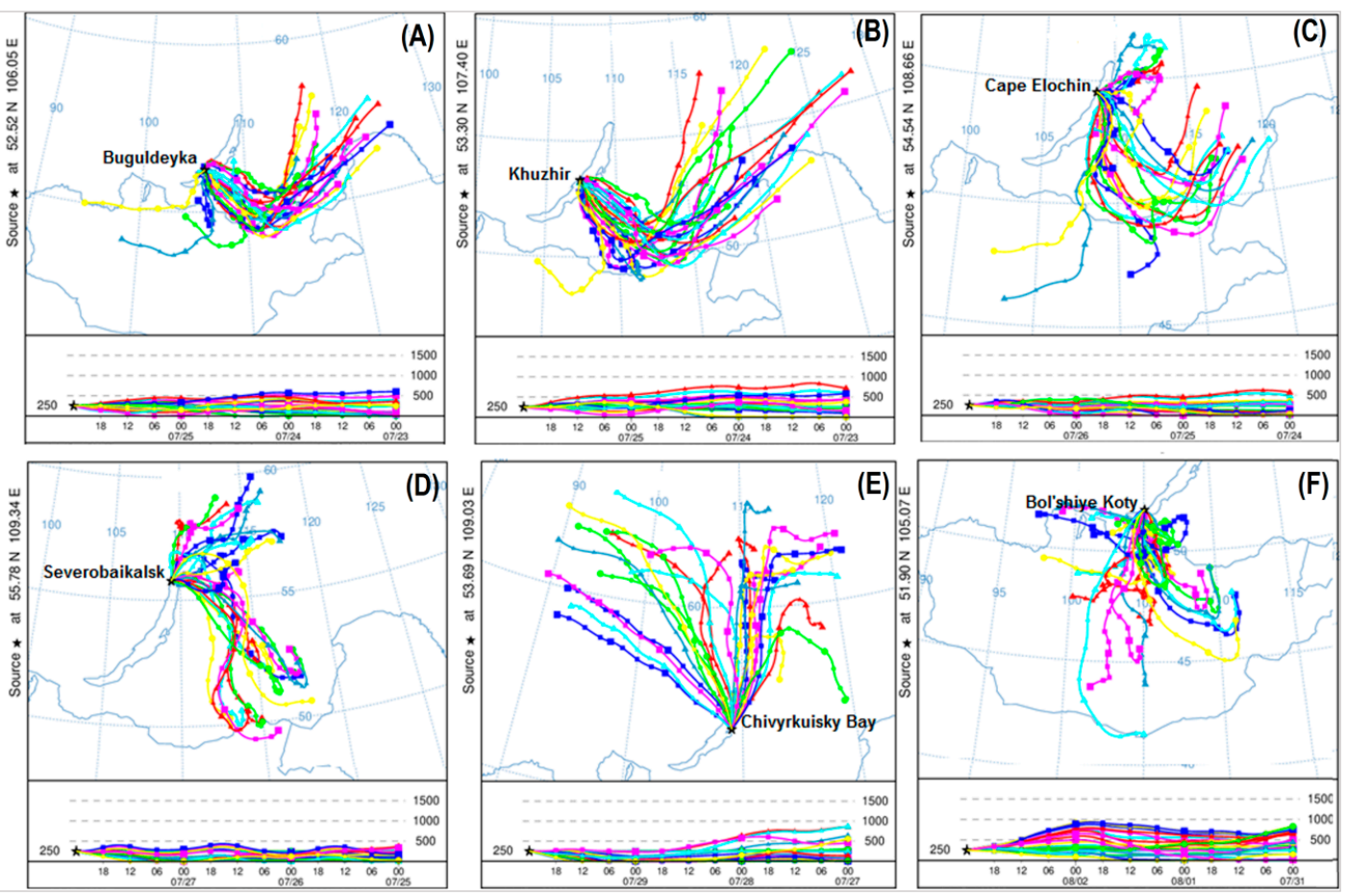

Figure 3. The air mass backward trajectories to Lake Baikal in July-August 2019: (A) 25 July, (B) 26 July, (C) 27 July, (D) 28 July, (E) 30 July, (F) 1 August [29].

Figure 4A-D shows the values of meteorological parameters at altitudes of up to $5000 \mathrm{~m}$ in the atmosphere of Central Baikal during the smog above the lake. In the lake basin, we recorded an inverse 
temperature distribution in the lower one-kilometer layer as well as abrupt changes in wind direction and wind speed, which resulted in a complex pattern of the aerosol distribution [33]. From the evening on 29 July to the night on 30 July, the smoke aerosol descended to the water surface of the lake and spread over the water area.

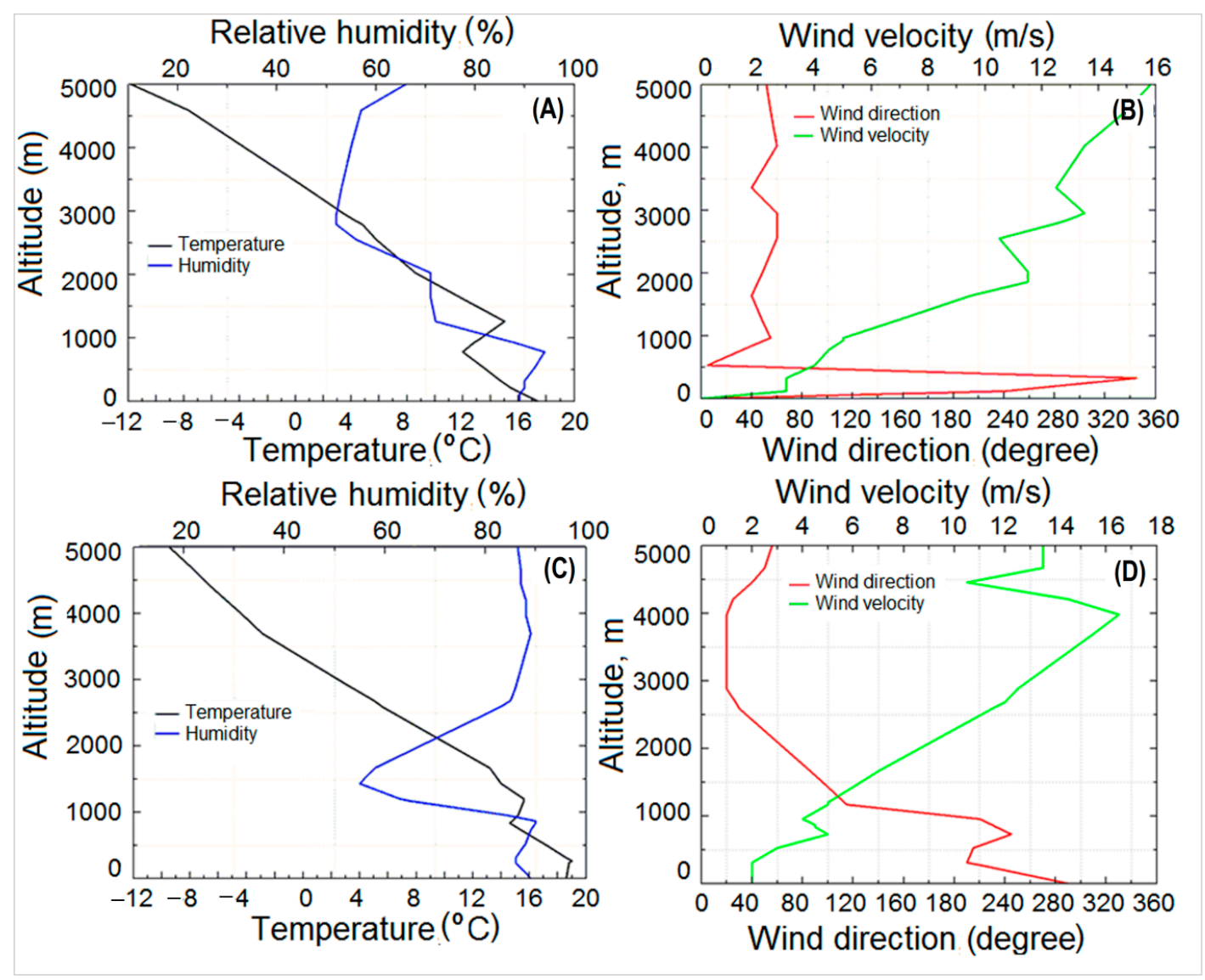

Figure 4. Dynamics of meteorological parameters in the atmosphere up to $5000 \mathrm{~m}$ in Central Baikal (weather station in Ust-Barguzin) at 8:00 on 29 July 2019 (A,B) and at 20:00 on 29 July 2019 (C,D) [33].

3.2. Spatial Distribution of the Mass, $M_{A}\left(\mu \mathrm{g} \mathrm{m} \mathrm{m}^{-3}\right)$, and Number, $N_{A}\left(\mathrm{~cm}^{-3}\right)$, Concentrations of Aerosol Particles

Table 1 shows the average mass concentrations of aerosol particles along the RV route in 2019. At the beginning of the route, we observed the elevated mass concentrations of particles during moorings of the RV in the area of Southern Baikal, in the Listvyanka settlement and the Baikalsk town (Table 1).

In the absence of the influence of wildfires, the anthropogenic factor mainly affected the increase in the mass concentration of particles. Along the eastern coast of the southern basin, there are large settlements with coal-fired boilers and suburban houses with stove heating, and federal highways and railways pass, polluting the atmosphere in this part of the lake. Complex orography of this area and the mountainous margin of the Khamar-Daban range with heights above $2300 \mathrm{~m}$ do not contribute to the dispersion of pollutants in the atmosphere. Other areas with the highest mass concentrations of aerosol were located on the east coast of Northern and Central Baikal on 30-31 July 2019 in Chivyrkuy and Barguzin bays. In the atmosphere of this area, we observed a smog from wildfires, which spread to the south along the RV route from Turka to Kharauz (delta of the Selenga River) and to Boyarsk. Background mass concentrations of particles were recorded along the northwestern coast on $25-27 \mathrm{July}\left(1.5-5.9 \mu \mathrm{g} / \mathrm{m}^{3}\right)$ and the northeastern coast of the lake on 28-29 July $\left(1.7-6.0 \mu \mathrm{g} / \mathrm{m}^{3}\right.$ ) (see Figure 1B, Table 1). 
Table 1. The average mass concentrations of aerosol particles along the RV route in 2019.

\begin{tabular}{|c|c|c|c|}
\hline Date & Route & $\begin{array}{c}\text { Average Mass } \\
\text { Concentration }\left(\mu \mathrm{g} / \mathrm{m}^{3}\right)\end{array}$ & $\begin{array}{c}\text { Concentration Range } \\
\qquad\left(\mu \mathrm{g} / \mathrm{m}^{3}\right)\end{array}$ \\
\hline 24 July 2019 & Listvyanka (stop) & 5.86 & $3.0-16.7$ \\
\hline \multirow{4}{*}{25 July 2019} & Baikalsk (stop) & 6.49 & \multirow{4}{*}{$1.5-8.3$} \\
\hline & Baikalsk-Listvyanka & 4.50 & \\
\hline & Listvyanka & 1.99 & \\
\hline & Listvyanka-Buguldeika & 2.56 & \\
\hline \multirow{3}{*}{26 July 2019} & Buguldeika-Ogoy & 3.50 & \multirow{3}{*}{$2.7-10.1$} \\
\hline & Ogoy-Khuzhir & 2.95 & \\
\hline & Khuzhir (stop) & 6.04 & \\
\hline \multirow{3}{*}{27 July 2019} & Khuzhir-Elokhin & 4.37 & \multirow{3}{*}{$2.9-14.8$} \\
\hline & Elokhin (stop) & 3.71 & \\
\hline & Elokhina-Kotelnikovsky & 9.55 & \\
\hline \multirow{3}{*}{28 July 2019} & Kotelnikovsky-Severobaikalsk & 9.31 & \multirow{3}{*}{$2.1-18.3$} \\
\hline & $\begin{array}{c}\text { Severobaikalsk-Nizhneangars } \\
\text { k-Severobaikalsk }\end{array}$ & 14.01 & \\
\hline & Severobaikalsk (stop) & 13.00 & \\
\hline \multirow{2}{*}{29 July 2019} & Severobaikalsk-Khakusy & 5.17 & \multirow{2}{*}{$1.7-23.6$} \\
\hline & Khakusy-Sosnovka & 13.36 & \\
\hline \multirow{2}{*}{30 July 2019} & Sosnovka-Zmeinaya & 36.35 & \multirow[b]{2}{*}{$10.6-62.3$} \\
\hline & Zmeinaya-Ust-Barguzin & 36.63 & \\
\hline \multirow{3}{*}{31 July 2019} & Ust-Barguzin (stop) & 41.32 & \multirow{3}{*}{$30.5-48.7$} \\
\hline & Ust-Barguzin-Turka & 40.89 & \\
\hline & Turka (stop) & 33.07 & \\
\hline \multirow{2}{*}{1 August 2019} & Turka-Kharauz & 36.20 & \multirow[b]{2}{*}{$13.7-40.4$} \\
\hline & Kharauz (stop) & 25.54 & \\
\hline \multirow{3}{*}{2 August 2019} & Kharauz-Boyarsk & 31.53 & \multirow{3}{*}{$7.7-42.0$} \\
\hline & Boyarsk (stop) & 34.85 & \\
\hline & Boyarsk (stop) & 12.15 & \\
\hline \multirow{3}{*}{3 August 2019} & Boyarsk-Baikalsk (stop) & 10.09 & \multirow{3}{*}{$5.4-15.5$} \\
\hline & Baikalsk-Bolshiye Koty & 7.60 & \\
\hline & Bolshiye Koty (stop) & 6.58 & \\
\hline 4 August 2019 & Bolshiye Koty-Listvyanka & 9.10 & $8.2-10.0$ \\
\hline
\end{tabular}

The distribution dynamics of the mass concentration of aerosol above Lake Baikal, depending on the anthropogenic factors, meteorological conditions and wildfires, differs significantly from year to year. In Table 2, we combined the average mass concentrations of the aerosol above different areas of the lake, which were measured from 2016 to 2019. The highest aerosol concentrations were recorded in July 2016 and July-August 2019 during extensive wildfires. In July 2016, in Southern and Central Baikal, there were local wildfires that engulfed the west coast of the lake; we observed significant air pollution with smoke. This was also observed (see Figure 2) in July-August 2019 when on the east coast of the lake near Sosnovka Bay, there was a local fire. Moreover, smoke aerosol was recorded from extensive sites of wildfires in the northern areas of the Irkutsk Region, the Krasnoyarsk Territory and the Republic of Sakha (Yakutia). In 2018, there was also some increase in the mass concentration of aerosol, which was associated both with local anthropogenic sources and regional wildfires [32]. 
Table 2. Average mass concentrations of aerosol above the Baikal basins in summers from 2016 to 2019, $\mu \mathrm{g} / \mathrm{m}^{3}$.

\begin{tabular}{cccc}
\hline Date & Southern Baikal & Central Baikal & Northern Baikal \\
\hline July 2016 & $19.0 \pm 8.2$ & $16.9 \pm 12.1$ & $7.9 \pm 5.5$ \\
\hline August 2016 & $6.3 \pm 3.7$ & $6.3 \pm 3.5$ & $4.2 \pm 2.0$ \\
\hline July 2017 & $2.8 \pm 1.2$ & $3.3 \pm 1.0$ & $2.7 \pm 1.7$ \\
\hline July 2018 & $10.9 \pm 5.8$ & $9.2 \pm 2.5$ & $5.3 \pm 3.0$ \\
\hline July-August 2019 & $9.7 \pm 8.7$ & $23.8 \pm 16.0$ & $16.2 \pm 15.8$ \\
\hline
\end{tabular}

The lowest mass concentration of aerosol was recorded in July 2017 when calm sunny weather without fires prevailed throughout the entire cruise of the RV.

The increase in the mass concentration of particles was correlated well with their number concentration. Figure 5 shows the dispersed composition of the aerosol. The proportion of submicron aerosol fraction is predominant and averages $99.1-99.5 \%$ of the total number concentration of particles above the lake.
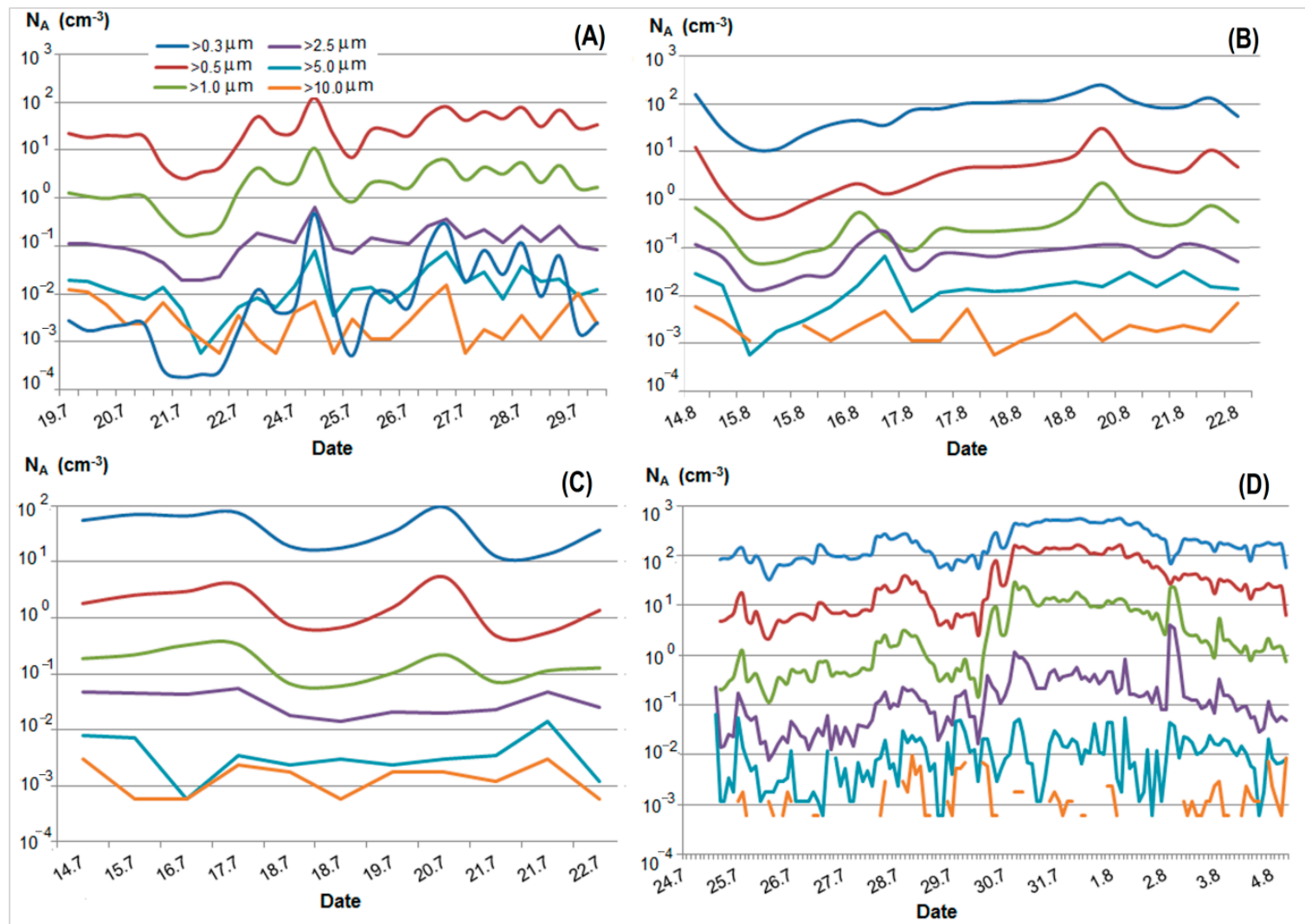

Figure 5. Number concentrations $\left(\mathbf{N}_{\mathbf{A}}\right)$ of the atmospheric aerosol in July 2016 (A), August 2016 (B), June 2017 (C), and July-August 2019 (D).

The number concentration of particles in July 2016 was elevated throughout the entire route of the RV and reached the maximum in Barguzin Bay (Figure 5A). In August 2016, an increase in the number concentration was also recorded in Barguzin Bay (Figure 5B). The number concentration, as well as the mass concentration, was the lowest in 2017, but on $20 \mathrm{July}$, we recorded its increase to $101.7 \mathrm{~cm}^{-3}$ near the delta of the Selenga River (Figure 4C), which was associated with the change in meteorological situation manifested in the strengthening of wind and the removal of polluted air masses along the valley of the Selenga River. 
The dynamics of the number concentration of aerosol particles in 2019 indicates that, like in 2016-2017, the changes affected a submicron part of the aerosol (up to $1.0 \mu \mathrm{m}$ in size) (Figure 5D). Air carrying mainly small combustion particles entered the lake basin. At the same time, an increase in the concentration of submicron particles was significant (two-fivefold) and continued from 30 July to 2 August, until the direction of air currents changed (see Figure 3).

\subsection{Spatiotemporal Distribution of Ionic Concentrations in Aerosol above the Water Area of Lake Baikal}

Many researchers have indicated the peculiar Baikal landscape surroundings and climate. The presence of mountain ranges around the Baikal basin leads to the formation of a unique climate both in seasonal and diurnal changes in the main meteorological characteristics, which long-term monitoring observations at the network of weather stations rather densely located on the lake coast confirm [35]. The most pollutant-free atmosphere above the water surface of Lake Baikal is located above the central abyssal part of the lake. Based on the 2005-2008 data, total ionic concentrations in the composition of aerosol varied from 0.1 to $0.7 \mu \mathrm{g} / \mathrm{m}^{3}$. The bulk of dissolved aerosol components was in the submicron size spectrum, accounting for approximately $60 \%$ of the total mass. Heterogeneity in the distribution of impurities above the surface of Lake Baikal was mainly observed in the estuarine areas of the large tributaries and bays as well as above Southern Baikal [30]. In Southern Baikal, substances are removed to the lake along the Angara River valley from the industrial areas of the Southern Baikal region in the form of poorly dispersed plumes during mesoscale jet stream transport in the atmospheric boundary layer [36]. Averaging the total ionic concentrations in the aerosols above each Baikal basin confirmed the previously revealed [37] trend of the latitudinal distribution of impurities with the highest accumulation above Southern Baikal and the lowest one above Northern Baikal [30].

Recent research (from 2010 to 2019) has indicated the significant variability of the revealed trend in the distribution of impurities in the near-water atmosphere above Lake Baikal due to climate change and an increase in wildfires in Siberia (Table 3).

Table 3. Variability of the average concentrations the sum of ions in the atmospheric aerosol of the near-water atmosphere above Lake Baikal in the warm season from 2010 to 2019, $\mu \mathrm{g} / \mathrm{m}^{3}$.

\begin{tabular}{cccc}
\hline Period & Southern Baikal & Central Baikal & Northern Baikal \\
\hline 2005-2008 & $1.47 \pm 0.75$ & $0.97 \pm 0.64$ & $0.84 \pm 0.50$ \\
\hline June 2010 & $2.12 \pm 1.09$ & $2.04 \pm 0.81$ & $1.27 \pm 0.59$ \\
\hline June 2012 & $5.25 \pm 1.31$ & $2.30 \pm 1.17$ & $2.66 \pm 0.44$ \\
\hline May 2014 & $0.62 \pm 0.24$ & $0.40 \pm 0.16$ & $0.26 \pm 0.10$ \\
\hline August 2014 & $0.55 \pm 0.17$ & $0.35 \pm 0.04$ & $0.62 \pm 0.30$ \\
\hline May 2015 & $0.33 \pm 0.00$ & $0.78 \pm 0.46$ & $0.24 \pm 0.08$ \\
\hline August 2015 & $1.62 \pm 1.02$ & $2.09 \pm 0.77$ & $1.49 \pm 0.56$ \\
\hline June 2016 & $2.25 \pm 0.73$ & $2.40 \pm 0.90$ & $3.18 \pm 0.80$ \\
\hline July 2016 & $0.45 \pm 0.61$ & $1.80 \pm 0.67$ & $2.58 \pm 0.57$ \\
\hline August 2016 & $1.08 \pm 0.83$ & $0.96 \pm 1.13$ & $0.64 \pm 0.45$ \\
\hline June 2017 & $0.38 \pm 0.09$ & $0.39 \pm 0.28$ & $0.21 \pm 0.16$ \\
\hline July 2017 & $1.22 \pm 0.96$ & $0.77 \pm 0.35$ & $0.61 \pm 0.16$ \\
\hline June 2018 & $2.90 \pm 1.41$ & $2.05 \pm 1.84$ & $0.93 \pm 0.62$ \\
\hline June 2019 & $0.36 \pm 0.24$ & $1.31 \pm 0.94$ & $0.82 \pm 0.43$ \\
\hline July 2019 & $4.04 \pm 1.71$ & $6.49 \pm 3.94$ & $2.63 \pm 1.22$ \\
\hline
\end{tabular}

The frequency of the average ionic concentrations below $1.0 \mu \mathrm{g} / \mathrm{m}^{3}$ from 2010 to 2019 was approximately $50 \%$, which corresponds to the natural background. The frequency of the average 
ionic concentrations above $2.0 \mu \mathrm{g} / \mathrm{m}^{3}$ became more than $30 \%$ (Figure 6). Taking into account that the impact of anthropogenic sources during the study period was relatively constant, wildfires in Siberia affected significantly the variability of soluble substances in the near-water atmosphere of the lake. The influence of smoke aerosol increased together with such meteorological events as high temperature, low humidity, and increased wind speed.

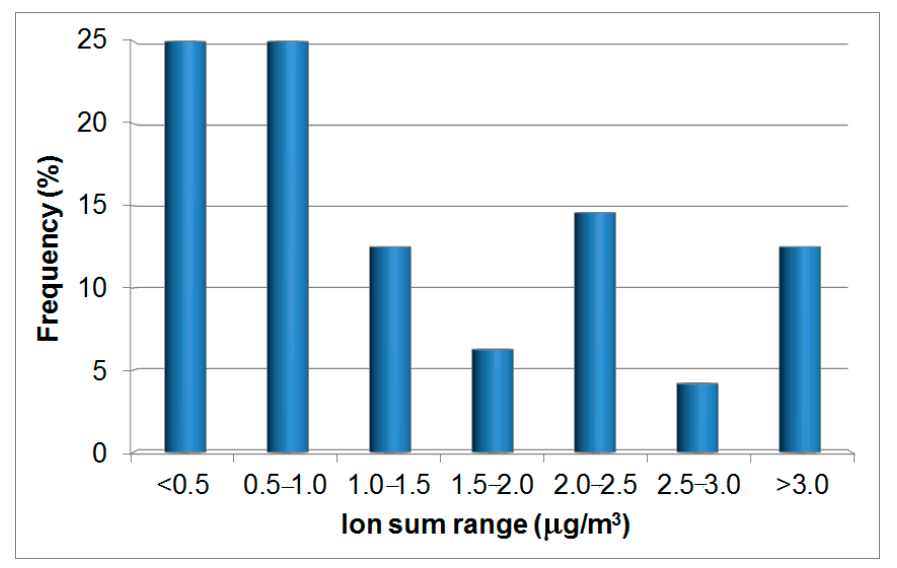

Figure 6. The frequency of the average concentrations the sum of ions in the composition of the atmospheric aerosol in the near-water atmospheric layer above Lake Baikal from 2010 to 2019.

Thus, abnormally dry windy weather in June 2012 in conjunction with the smoke aerosol increased the air pollution above the entire water area of the lake (see Table 3) [31]. Wildfires in 2015 and 2016 and especially in 2019 also contributed to the increase in pollutants in the near-water atmosphere above the lake (see Table 2).

Wildfires in July-August 2019, which engulfed large areas of Siberia, significantly affected the distribution of impurities in the atmosphere above the lake (see Table 1). Form 24 July to 4 August 2019, the total ionic concentrations varied from 1.2 to $11.2 \mu \mathrm{g} / \mathrm{m}^{3}$, and their upper limit was the highest over the entire long-term observation period. Based on averaged data, the predominant ions in the aerosol composition were $\mathrm{Na}^{+}, \mathrm{NH}_{4}{ }^{+}, \mathrm{NO}_{3}{ }^{-}$, and $\mathrm{SO}_{4}{ }^{2-}$ in the southern basin and $\mathrm{NH}_{4}{ }^{+}, \mathrm{NO}_{3}{ }^{-}$and $\mathrm{SO}_{4}{ }^{2-}$ in the central and northern basins. In the aerosol of Central Baikal, where a local fire was recorded, the concentrations of $\mathrm{K}^{+}$ions were higher than in other areas. Among other ions, the concentrations of $\mathrm{Cl}^{-}$and $\mathrm{Ca}^{2+}$ were increased in aerosol (Table 4).

Table 4. Average values and standard deviations of the ionic concentrations in the composition of atmospheric aerosol in the near-water atmosphere of Lake Baikal (from 24 July to 4 August 2019).

\begin{tabular}{cccc}
\hline Element & Southern Baikal & Central Baikal & Northern Baikal \\
\hline $\mathrm{Na}^{+}$ & $0.56 \pm 0.75$ & $0.14 \pm 0.04$ & $0.12 \pm 0.06$ \\
\hline $\mathrm{NH}_{4}{ }^{+}$ & $0.89 \pm 0.73$ & $2.19 \pm 1.32$ & $0.86 \pm 0.53$ \\
\hline $\mathrm{K}^{+}$ & $0.07 \pm 0.05$ & $0.19 \pm 0.13$ & $0.10 \pm 0.07$ \\
\hline $\mathrm{Mg}^{2+}$ & $0.05 \pm 0.03$ & $0.04 \pm 0.01$ & $0.04 \pm 0.02$ \\
\hline $\mathrm{Ca}^{2+}$ & $0.21 \pm 0.13$ & $0.20 \pm 0.07$ & $0.16 \pm 0.06$ \\
\hline $\mathrm{Cl}^{-}$ & $0.16 \pm 0.25$ & $0.17 \pm 0.11$ & $0.19 \pm 0.12$ \\
\hline $\mathrm{NO}_{3}{ }^{-}$ & $0.49 \pm 0.39$ & $0.73 \pm 0.69$ & $0.36 \pm 0.31$ \\
\hline $\mathrm{SO}_{4}{ }^{2-}$ & $1.60 \pm 1.46$ & $2.83 \pm 2.07$ & $0.79 \pm 0.31$ \\
\hline
\end{tabular}

In previous years of measurements, during the periods of smoke-free atmosphere, the major ions in the aerosol composition were $\mathrm{NH}_{4}{ }^{+}, \mathrm{Ca}^{2+}$, and $\mathrm{SO}_{4}{ }^{2-}$; under the impact of meteorological factors- $\mathrm{Na}^{+}$, 
$\mathrm{K}^{+}, \mathrm{Ca}^{2+}, \mathrm{Cl}^{-}$, and $\mathrm{SO}_{4}{ }^{2-}$; in the atmosphere with smoke from nearby fires- $\mathrm{Na}^{+}, \mathrm{NH}_{4}{ }^{+}, \mathrm{K}^{+}, \mathrm{Ca}^{2+}, \mathrm{Cl}^{-}$, and $\mathrm{SO}_{4}{ }^{2-}$; in the atmosphere with smoke from distant fires- $\mathrm{NH}_{4}{ }^{+}, \mathrm{K}^{+}, \mathrm{Cl}^{-}, \mathrm{NO}_{3}{ }^{-}$, and $\mathrm{SO}_{4}{ }^{2-}[30,31]$.

Depending on the type of biomass burnt, volatile inorganic elements condense in the form of chlorides and sulfates into a group of particles enriched in potassium [38-40]. We calculated enrichment factors for these elements for each sample using the formula from [41].

$$
K_{i}=\left[\left(\frac{C_{i}}{N a^{+}}\right)_{a e r} /\left(\frac{C_{i}}{N a^{+}}\right)_{B W}\right]
$$

where $K$-enrichment factor, $\left(\frac{\mathrm{C}_{i}}{\mathrm{Na}}\right)$-the concentration of $i$ th element relative to $\mathrm{Na}^{+}$in the aerosol (aer) and Baikal water $(B W)$ [42].

Enrichment factors for the $\mathrm{K}^{+}(\mathrm{K}=2 \div 14)$ and $\mathrm{SO}_{4}{ }^{2-}(\mathrm{K}=5 \div 25)$ ions had similar dynamics and were the highest in the aerosol along the east coast, from Northern (Khakusy Bay) to Southern (the Boyarsk settlement) Baikal (see Figure 1B), where smog was recorded. We determined the highest enrichment factors for the $\mathrm{Cl}^{-}(\mathrm{K}=5 \div 26)$ ions in the aerosol on the west coast during the $\mathrm{RV}$ route along the southern margin of the lake. The recalculation of the ionic enrichment factors relative to the concentrations of the elements in the Earth's crust revealed the same pattern as in the calculation relative to the concentration of ions in Baikal water. At the same time, the enrichment factors of $\mathrm{Ca}^{2+}$ were close to one above the entire water area of the lake. This indicates a predominantly soil origin of the aerosol affected by the smoke emission.

We carried out a correlation analysis of the ionic composition and the dispersion of the aerosol. The analysis revealed that the $\mathrm{NH}_{4}{ }^{+}$and $\mathrm{K}^{+}$ions are absorbed mainly on submicron aerosol particles of $0.3-1.0 \mu \mathrm{m}$ in size. The correlation coefficients (r) varied from $0.92-0.95$ for the particles ranging between 0.3 and $0.5 \mu \mathrm{m}$ to $0.82-0.84$ for the particles with a size of $0.1 \mu \mathrm{m}$. The large particles of 2.5-5.0 $\mu \mathrm{m}$ showed a lower correlation of these ions $(\mathrm{r}=0.26-0.42)$. We also determined a high correlation for the concentrations of the $\mathrm{NO}_{3}{ }^{-}$and $\mathrm{SO}_{4}{ }^{2-}$ with the particles ranging from 0.3 to $0.5 \mu \mathrm{m}(\mathrm{r}=0.55-0.66)$ and the $1.0 \mu \mathrm{m}$ particles $(\mathrm{r}=0.44-0.54)$. The concentrations of the $\mathrm{Ca}^{2+}(\mathrm{r}=0.25)$ and $\mathrm{NO}_{3}{ }^{-}(\mathrm{r}=0.31)$ showed loose correlation with particles of $5.0 \mu \mathrm{m}$ in size.

\subsection{Polyaromatic Compounds (PAHs) in the Composition of the Near-Water Aerosol}

Wildfires are considered one of the PAH sources entering natural environments. PAH compounds resulting from burning natural materials are called pyrogenic. These include compounds with a high molecular weight. Based on the sum concentrations of fourteen identified PAHs (naphthalene, acenaphthylene, acenaphthene, fluorene, phenanthrene, anthracene, fluoranthene, pyrene, benzo[a]anthracene, chrysene, benzo[b]fluoranthene, benzo[k]fluoranthene, benzo[e]pyrene, and benzo[a]pyrene), we investigated in detail the influence of wildfires on the pollution of the near-water atmosphere above Lake Baikal in 2015 and 2016. In August 2015, the fire site was a short distance from on the coast Central Baikal; in 2016, the atmosphere above Lake Baikal was covered with smoke from regional fires that were spread over time. During the so-called "fresh" fire in August 2015, there were the highest concentrations of PAHs, in total varying from $1.6 \mathrm{ng} / \mathrm{m}^{3}$ to $152.1 \mathrm{ng} / \mathrm{m}^{3}$. In contrast, in May 2015, in the absence of fires, the sum of concentrations of PAHs in the aerosol ranged from 0.9 to $2.4 \mathrm{ng} / \mathrm{m}^{3}$. Phenanthrene, the proportion of which varied from 8 to $66 \%$ of the sum of concentrations of PAHs, naphthalene $(0.4-66 \%)$, fluorene $(0-46 \%)$, fluoranthene (1-38\%), and pyrene (1-24\%) dominated the identified PAHs. According to the published data, these compounds resulted from burning coniferous and larch forests [43-45]. Their total number reached on average $81 \%$ of all determined compounds, with a predominance of phenanthrene (on average $27 \%$ ) and naphthalene (on average $26 \%$ ). Notably, according to [46] naphthalene and phenanthrene also resulted from the combustion of fossil fuels. The influence of pyrogenic and petrogenic PAH sources can be determined from the ratio of the fluoranthene/(fluoranthene + pyrene) concentrations. The ratio above 0.4 characterizes the presence of pyrogenic sources, and that below 0.4-petrogenic sources [47]. In our case, the concentration ratio of these compounds ranged from 0.41 to 0.64 during the entire cruise, which indicates pyrogenic sources. 
In July 2016, the sum of concentrations of PAHs in the aerosol was lower and varied within a narrower range from 6.3 to $42.4 \mathrm{ng} / \mathrm{m}^{3}$. The concentrations of individual PAHs, as well as their share, were lower. In 2016, the set of predominant PAHs in the aerosol differed from its composition in 2015. Perhaps, the long presence of the smoke aerosol in the atmosphere contributed to the deposition of heavy molecules. Naphthalene $(0.3-82 \%)$, chrysene $(0-34 \%)$, phenanthrene $(0.1-27 \%)$, pyrene $(0-25 \%)$, fluorene $(0.0-10.4 \%)$, and fluoranthene $(0.3-5.6 \%)$ dominated PAHs. During almost the entire cruise, the ratio of the fluoranthene/(fluoranthene + pyrene) concentrations was below 0.4 . Only by the end of the cruise, this ratio changed to $0.47-0.57$ near the delta of the Selenga River. An analysis of the variability in the concentrations of PAHs has revealed that the composition of PAHs in the aerosol coming from distant (regional) wildfires differs significantly from the PAH composition resulting from the sites of local fires in the immediate vicinity of the lake.

In 2019, the atmosphere experienced the influence of distant and local fires. Table 5 shows the variability of PAH concentrations in the aerosol in July 2019.

Table 5. Concentrations of PAHs in the aerosol of the near-water atmosphere above Lake Baikal along the route of the RV «Akademik V.A. Koptyug» from 24 July to 4 August 2019 (number of samples is given in parentheses).

\begin{tabular}{|c|c|c|c|c|c|}
\hline No & Baikal & Route & Date & $\begin{array}{l}\text { The Sum of } \\
\text { PAHs, } \mathrm{ng} / \mathrm{m}^{3}\end{array}$ & $\begin{array}{l}\text { Range of Sum } \\
\text { PAHs, ng/m }\end{array}$ \\
\hline 1 & \multirow{2}{*}{ Southern Baikal } & Baikalsk (stop) & 24-25 July & 1.16 & (1) \\
\hline 2 & & Listvyanka-Buguldeika & 25 July & $0.30 \pm 0.09$ & $0.22 \div 0.41(4)$ \\
\hline 3 & Central Baikal & Buguldeika-Khuzhir & 25-26 July & $0.26 \pm 0.01$ & $0.25 \div 0.27(3)$ \\
\hline 4 & \multirow{4}{*}{$\begin{array}{l}\text { Northern } \\
\text { Baikal }\end{array}$} & Khuzir-Severobaikalsk & 26-28 July & $0.25 \pm 0.13$ & $0.11 \div 0.42(4)$ \\
\hline 5 & & Severobaikalsk (stop) & 28 July & 0.29 & (1) \\
\hline 6 & & Severobaikalsk-Sosnovka Bay & 28-29 July & $0.19 \pm 0.05$ & $0.15 \div 0.22(2)$ \\
\hline 7 & & Sosnovka Bay-Zmeinaya Base & 29-30 July & 0.99 & (1) \\
\hline 8 & \multirow{6}{*}{ Central Baikal } & Zmeinaya Base-Ust-Barguzin & 30 July & 1.29 & $(1)$ \\
\hline 9 & & Ust-Barguzin (stop) & 30-31 July & 1.66 & (1) \\
\hline 10 & & Ust-Barguzin-Turka & 31 July & 1.06 & $(1)$ \\
\hline 11 & & Turka (stop) & 31 July & 2.01 & (1) \\
\hline 12 & & Turka-Kharauz & $\begin{array}{l}31 \text { July-1 } \\
\text { August }\end{array}$ & 1.43 & $(1)$ \\
\hline 13 & & Kharauz (stop) & 1 August & 4.62 & (1) \\
\hline 14 & \multirow{3}{*}{ Southern Baikal } & Kharauz-Boyarsk & 1-2 August & 2.00 & $(1)$ \\
\hline 15 & & Boyarsk (stop) & 2-3 August & $2.40 \pm 0.07$ & $2.35 \div 2.45(2)$ \\
\hline 16 & & Boyarsk-Bolshie Koty & 2-3 August & $0.75 \pm 0.24$ & $0.55 \div 1.02(3)$ \\
\hline
\end{tabular}

In 2019, the sum of PAHs ranged from 0.11 to $4.62 \mathrm{ng} / \mathrm{m}^{3}$ and were significantly lower than in 2015 and 2016, despite the wider range of various compounds (18 PAH compounds) (Table 6). Among individual PAHs, acenaphthylene (1.8-10.5\%), phenanthrene (12.6-17.9\%), fluoranthene (9.4-14.7\%), benzo[b]fluoranthene (5.8-9.8\%), benzo[a]pyrene (6.2-7.7\%), indeno[1,2,3-c,d]pyrene (2.7-12.2\%), and benzo[g,h,i]perylene $(2.4-13.8 \%)$ prevailed in the aerosol of Southern Baikal and along the west coast. Most of these compounds are indicators of the anthropogenic pollution [46,48]. The benzo[a]pyrene/benzo[g,h,i]perylene ratio below 0.6 indicates emissions from vehicles near the Baikalsk town (Southern Baikal), and that above 0.6 -from the stationary sources in the aerosol sampled along the west coast from Southern to Central Baikal. The indeno[1,2,3-c,d]pyrene/indeno[1,2,3-c,d]pyrene+ benzo[g,h,i]perylene ratio below 0.5 in the aerosol composition of these areas indicates the combustion of liquid fuel [47]. The PAH composition changed in the aerosol under the influence of the smog in Northern and Central Baikal (see Table 6). Phenanthrene (3.4-14.3\%), fluoranthene (11.4-24.5\%), benzo[b]fluoranthene (10.7-20.7\%), indeno[1,2,3-c,d]pyrene (4.2-11.8\%), benzo[k]fluoranthene (3.8-11.7\%), pyrene (9.9-15.4\%), and benzo[g,h,i]perylene (3.9-10.4\%) were dominant compounds. The diagnostic ratios of the PAH concentrations indicate mainly pyrogenic sources of these compounds. 
Table 6. Concentrations of individual PAHs in the composition of the aerosol in the near-water layer above Lake Baikal along the route of the RV «Akademik V.A. Koptyug» from 24 July to 4 August 2019, ng/m³ (the RV route 1-16 see in the Table 5).

\begin{tabular}{|c|c|c|c|c|c|c|c|c|c|c|c|c|c|c|c|c|}
\hline PAH & 1 & 2 & 3 & 4 & 5 & 6 & 7 & 8 & 9 & 10 & 11 & 12 & 13 & 14 & 15 & 16 \\
\hline Naphthalene & 0.035 & 0.019 & 0.013 & 0.016 & 0.018 & 0.011 & 0.021 & 0.024 & 0.027 & 0.031 & 0.021 & 0.012 & 0.042 & 0.009 & 0.023 & 0.024 \\
\hline Acenaphthylene & 0.000 & 0.000 & 0.000 & 0.000 & 0.000 & 0.000 & 0.000 & 0.000 & 0.000 & 0.000 & 0.000 & 0.000 & 0.000 & 0.000 & 0.000 & 0.000 \\
\hline Azenaften & 0.021 & 0.024 & 0.027 & 0.018 & 0.018 & 0.010 & 0.012 & 0.013 & 0.013 & 0.035 & 0.030 & 0.012 & 0.046 & 0.016 & 0.044 & 0.064 \\
\hline Fluoren & 0.067 & 0.027 & 0.019 & 0.014 & 0.015 & 0.009 & 0.018 & 0.017 & 0.015 & 0.032 & 0.021 & 0.010 & 0.027 & 0.011 & 0.027 & 0.029 \\
\hline Phenanthrene & 0.138 & 0.043 & 0.046 & 0.039 & 0.048 & 0.024 & 0.072 & 0.076 & 0.025 & 0.111 & 0.089 & 0.066 & 0.157 & 0.084 & 0.129 & 0.100 \\
\hline Anthracene & 0.031 & 0.008 & 0.014 & 0.009 & 0.011 & 0.004 & 0.008 & 0.016 & 0.018 & 0.014 & 0.010 & 0.004 & 0.013 & 0.005 & 0.007 & 0.001 \\
\hline Fluorantin & 0.123 & 0.027 & 0.029 & 0.035 & 0.032 & 0.026 & 0.115 & 0.146 & 0.231 & 0.259 & 0.395 & 0.258 & 0.783 & 0.372 & 0.420 & 0.159 \\
\hline Pyrene & 0.082 & 0.020 & 0.025 & 0.029 & 0.023 & 0.017 & 0.103 & 0.100 & 0.157 & 0.162 & 0.233 & 0.160 & 0.467 & 0.225 & 0.237 & 0.080 \\
\hline $\begin{array}{c}\text { Benz [a] } \\
\text { anthracene }\end{array}$ & 0.032 & 0.008 & 0.006 & 0.016 & 0.010 & 0.004 & 0.006 & 0.022 & 0.052 & 0.020 & 0.013 & 0.020 & 0.057 & 0.029 & 0.060 & 0.010 \\
\hline Chrysen & 0.033 & 0.012 & 0.016 & 0.021 & 0.016 & 0.010 & 0.033 & 0.076 & 0.096 & 0.081 & 0.125 & 0.088 & 0.355 & 0.132 & 0.129 & 0.042 \\
\hline $\begin{array}{c}\text { Benz [b] } \\
\text { fluoranthene }\end{array}$ & 0.081 & 0.020 & 0.015 & 0.037 & 0.022 & 0.019 & 0.170 & 0.230 & 0.280 & 0.109 & 0.392 & 0.280 & 0.994 & 0.414 & 0.391 & 0.099 \\
\hline $\begin{array}{c}\text { Benz [k] } \\
\text { fluoranthene }\end{array}$ & 0.074 & 0.015 & 0.010 & 0.031 & 0.015 & 0.010 & 0.116 & 0.107 & 0.155 & 0.040 & 0.147 & 0.112 & 0.299 & 0.139 & 0.188 & 0.033 \\
\hline Benz [a] pyrene & 0.083 & 0.022 & 0.016 & 0.038 & 0.024 & 0.015 & 0.033 & 0.060 & 0.138 & 0.026 & 0.068 & 0.063 & 0.202 & 0.077 & 0.130 & 0.018 \\
\hline Perylene & 0.009 & 0.002 & 0.001 & 0.006 & 0.003 & 0.001 & 0.003 & 0.011 & 0.020 & 0.003 & 0.006 & 0.004 & 0.014 & 0.009 & 0.012 & 0.000 \\
\hline $\begin{array}{c}\text { Indeno }[1,2,3-c, d] \\
\text { pyrene }\end{array}$ & 0.141 & 0.019 & 0.007 & 0.035 & 0.014 & 0.010 & 0.108 & 0.151 & 0.174 & 0.044 & 0.142 & 0.115 & 0.356 & 0.152 & 0.215 & 0.029 \\
\hline $\begin{array}{l}\text { Benzo }[\mathrm{g}, \mathrm{h}, \mathrm{i}] \\
\text { perylene }\end{array}$ & 0.159 & 0.022 & 0.006 & 0.035 & 0.012 & 0.009 & 0.088 & 0.134 & 0.131 & 0.041 & 0.135 & 0.107 & 0.333 & 0.140 & 0.195 & 0.025 \\
\hline $\begin{array}{c}\text { Dibenz }[\mathrm{a}, \mathrm{h}] \\
\text { anthracene }\end{array}$ & 0.000 & 0.000 & 0.000 & 0.003 & 0.000 & 0.000 & 0.000 & 0.000 & 0.012 & 0.000 & 0.000 & 0.000 & 0.000 & 0.000 & 0.013 & 0.000 \\
\hline
\end{tabular}


The comparison of the 2019 data with similar studies in 2015 and 2016 indicated that the PAH composition in the aerosol of this period was more identical to the PAH composition in 2016. The low contribution of the predominant phenanthrene, fluoranthene, and pyrene compounds in the aerosol indicates the influence of smoke emission from wildfires occurring in distant areas.

\subsection{Elemental Composition of the Near-Water Aerosol above Lake Baikal}

A detailed analysis of the variability of the concentrations for 26 elements in the aerosol above the lake revealed several periods during the cruise, in which their concentrations increased relative to the average values calculated for all the samples obtained (Figure 7, Table 7).

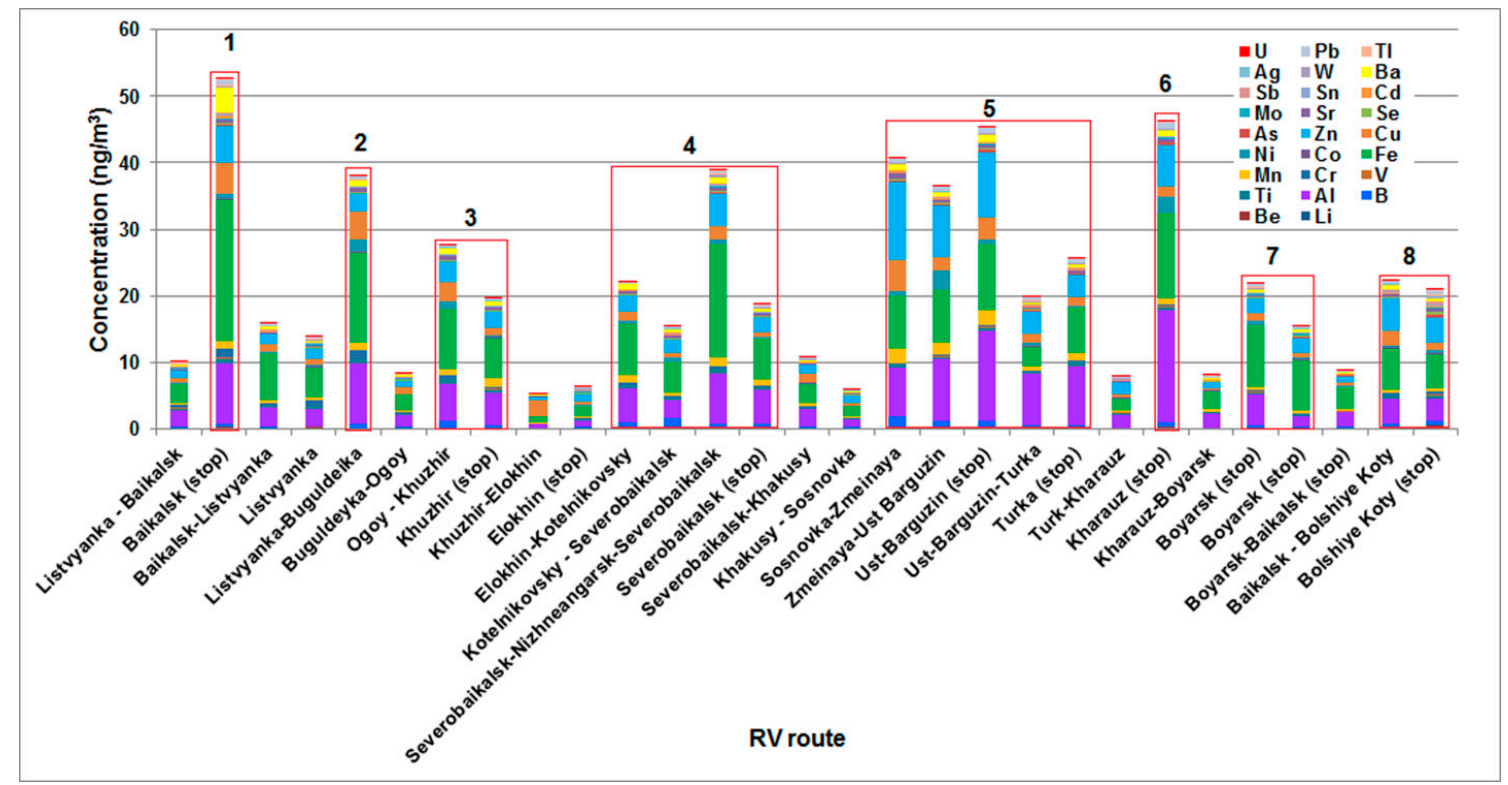

Figure 7. Variability of the elemental composition in the aerosol of the near-water atmospheric layer above Lake Baikal along the route of the RV «Akademik V.A. Koptyug» from 24 July to 4 August 2019, $\mathrm{ng} / \mathrm{m}^{3}$. 1-Baikalsk (stop), 2-the RV route Listvyanka-Buguldeika, 3-the RV route Ogoy-Khuzhir (stop), 4-the RV route Elokhin-Kotelnikovsky, 5-the RV route Socnobka-Turka (stop), 6-Kharauz (stop), 7-Boyarsk (stop), 8-the RV route Baikalsk-Djlshie Koty (stop). 
Table 7. Elemental composition of the aerosol in the near-water atmospheric layer above Lake Baikal along the route of the RV «Akademik V.A. Koptyug» from 24 July to 4 August 2019, ng/m³ . (The values in bold type those exceeding the average values).

\begin{tabular}{|c|c|c|c|c|c|c|c|c|c|c|}
\hline \multirow[t]{2}{*}{ Element } & \multirow[t]{2}{*}{ Background } & \multicolumn{8}{|c|}{$\begin{array}{l}\text { Study Areas with Elevated Concentrations of the Elements in the Aerosol } \\
\text { (Figure 7) }\end{array}$} & \multirow{2}{*}{$\begin{array}{c}\text { Overall } \\
\text { Average } \\
\text { Value }\end{array}$} \\
\hline & & No. 1 & No. 2 & No. 3 & No. 4 & No. 5 & No. 6 & No. 7 & No. 8 & \\
\hline $\mathrm{Li}$ & 0.06 & 0.20 & 0.08 & 0.10 & 0.11 & 0.09 & 0.18 & 0.10 & 0.19 & 0.10 \\
\hline $\mathrm{Be}$ & 0.06 & 0.16 & 0.07 & 0.09 & 0.09 & 0.07 & 0.09 & 0.09 & 0.18 & 0.08 \\
\hline B & 0.18 & 0.39 & 0.59 & 0.80 & 0.11 & 0.09 & 16.83 & 0.10 & 0.19 & 0.53 \\
\hline $\mathrm{Al}$ & 1.94 & 9.09 & 9.05 & 5.14 & 5.12 & 9.32 & 16.4 & 3.19 & 3.51 & 5.07 \\
\hline $\mathrm{Ti}$ & 0.18 & 0.71 & 0.65 & 0.48 & 0.43 & 0.41 & 0.48 & 0.22 & 0.39 & 0.34 \\
\hline $\mathrm{V}$ & 0.07 & 0.21 & 0.10 & 0.13 & 0.12 & 0.14 & 0.24 & 0.12 & 0.21 & 0.12 \\
\hline $\mathrm{Cr}$ & 0.25 & 1.32 & 1.40 & 0.45 & 0.29 & 0.24 & 0.27 & 0.24 & 0.37 & 0.35 \\
\hline $\mathrm{Mn}$ & 0.25 & 1.04 & 1.04 & 1.10 & 0.89 & 1.50 & 0.83 & 0.38 & 0.43 & 0.71 \\
\hline $\mathrm{Fe}$ & 2.91 & 21.4 & 13.6 & 7.55 & 8.87 & 7.17 & 12.8 & 8.45 & 5.67 & 6.71 \\
\hline $\mathrm{Co}$ & 0.06 & 0.17 & 0.08 & 0.10 & 0.11 & 0.08 & 0.11 & 0.10 & 0.18 & 0.09 \\
\hline $\mathrm{Ni}$ & 0.13 & 0.70 & 1.82 & 0.75 & 0.51 & 0.93 & 2.43 & 0.43 & 0.38 & 0.56 \\
\hline $\mathrm{Cu}$ & 0.86 & 4.61 & 4.22 & 1.84 & 1.14 & 2.48 & 1.46 & 0.94 & 1.62 & 1.57 \\
\hline $\mathrm{Zn}$ & 1.09 & 5.56 & 2.60 & 2.78 & 2.82 & 7.23 & 6.39 & 2.16 & 4.36 & 3.19 \\
\hline As & 0.08 & 0.21 & 0.10 & 0.11 & 0.12 & 0.25 & 0.24 & 0.13 & 0.22 & 0.14 \\
\hline Se & 0.10 & 0.22 & 0.15 & 0.15 & 0.17 & 0.17 & 0.16 & 0.17 & 0.33 & 0.15 \\
\hline $\mathrm{Sr}$ & 0.13 & 0.46 & 0.61 & 0.48 & 0.43 & 0.50 & 0.43 & 0.20 & 0.39 & 0.32 \\
\hline Mo & 0.07 & 0.27 & 0.08 & 0.09 & 0.09 & 0.07 & 0.09 & 0.09 & 0.18 & 0.09 \\
\hline $\mathrm{Ag}$ & 0.05 & 0.15 & 0.06 & 0.08 & 0.08 & 0.07 & 0.08 & 0.09 & 0.17 & 0.08 \\
\hline $\mathrm{Cd}$ & 0.07 & 0.24 & 0.09 & 0.11 & 0.11 & 0.21 & 0.17 & 0.10 & 0.24 & 0.13 \\
\hline Sn & 0.06 & 0.23 & 0.09 & 0.10 & 0.10 & 0.08 & 0.10 & 0.10 & 0.21 & 0.09 \\
\hline $\mathrm{Sb}$ & 0.06 & 0.24 & 0.08 & 0.10 & 0.11 & 0.08 & 0.12 & 0.11 & 0.24 & 0.10 \\
\hline $\mathrm{Ba}$ & 0.21 & 3.81 & 0.78 & 0.67 & 0.63 & 0.73 & 0.85 & 0.45 & 0.54 & 0.59 \\
\hline W & 0.06 & 0.17 & 0.08 & 0.10 & 0.19 & 0.07 & 0.09 & 0.14 & 0.21 & 0.10 \\
\hline $\mathrm{Tl}$ & 0.05 & 0.15 & 0.06 & 0.08 & 0.08 & 0.07 & 0.08 & 0.09 & 0.17 & 0.08 \\
\hline $\mathrm{Pb}$ & 0.16 & 0.71 & 0.47 & 0.19 & 0.22 & 0.63 & 0.91 & 0.31 & 0.37 & 0.33 \\
\hline $\mathrm{U}$ & 0.05 & 0.15 & 0.07 & 0.08 & 0.08 & 0.06 & 0.07 & 0.09 & 0.17 & 0.07 \\
\hline
\end{tabular}

Table 7 shows the average concentrations of the elements for each period defined, from 1 to 8 (see Figure 7), in comparison with the overall average value. The Background column shows the averaged data for the periods with the minimum concentrations of elements, and the values in bold type those exceeding the average values (see Table 7). Based on the data averaged for the entire period, with the concentrations above $1.0 \mathrm{ng} / \mathrm{m}^{3}$, we identified the elements $(\mathrm{Fe}, \mathrm{Al}, \mathrm{Cu}$, and $\mathrm{Zn}$ ), whose contributions varied up to $80.0 \%$ of their total amount. The contribution of the elements with the concentrations ranging within $0.1 \div 1.0 \mathrm{ng} / \mathrm{m}^{3}$ was approximately $15.0 \% ; \mathrm{Mn}, \mathrm{V}, \mathrm{Cr}, \mathrm{Ni}, \mathrm{Sr}, \mathrm{Ti}, \mathrm{As}$, $\mathrm{Se}, \mathrm{Ba}, \mathrm{Pb}$, and $\mathrm{Cd}$ were most common in this concentration range.

The concentrations of elements in the aerosol during the defined sampling periods (No. $1 \div$ No.8 see Table 7, Figure 7) differed in absolute values of the concentrations, which varied upward and downward. The highest concentrations of elements were recorded in the aerosol collected during the RV mooring in the Baikalsk town on 25 July 2019 (No. 1, see Table 7). As noted above, the anthropogenic factor affects more the southern margin of the lake. The area limited by high-mountain ranges and the northwestern transport of air masses prevailing here contribute to the accumulation of impurities in the atmosphere.

Along the west coast of the lake, from the Listvyanka settlement to the Khuzhir settlement (No. 2, No. 3, Table 7), elevated concentrations of elements in the aerosol were mainly of lithogenic origin. The Southwest coast of Southern Baikal and the area of the Maloye More Strait have weak easily 
decaying soil and vegetation cover with steppe and forest-steppe zones. The northernmost margin of the lake (No. 4, Table 7), as well as the southern one, experiences the anthropogenic impact due to the large settlements (the Severobaikalsk town and the Nizhneangarsk settlement) located on the coast.

Of greatest interest was the elemental composition of the aerosol in the influence zone of wildfires (No. 5). Owing to the studies conducted in different areas of Siberia and the East Kazakhstan Region, the chemical elements were divided into two groups in terms of the nature of their behavior during wildfires: the group of active air migrants, including $\mathrm{Cd}, \mathrm{Pb}, \mathrm{As}, \mathrm{Sb}, \mathrm{Se}, \mathrm{Mn}, \mathrm{Zn}, \mathrm{U}$, and $\mathrm{Sr}$, and the group of elements that accumulated in the burned area were $\mathrm{Cr}, \mathrm{Ni}, \mathrm{Co}, \mathrm{V}, \mathrm{Th}, \mathrm{Mg}, \mathrm{K}, \mathrm{Na}, \mathrm{Ca}$, and Al [49]. During our studies, when the atmosphere was affected by smoke emissions, the following elements had elevated concentrations: $\mathrm{Ti}, \mathrm{V}, \mathrm{Mn}, \mathrm{Fe}, \mathrm{Ni}, \mathrm{Co}, \mathrm{Cu}, \mathrm{Zn}, \mathrm{As}, \mathrm{Se}, \mathrm{Sr}, \mathrm{Cd}, \mathrm{Ba}$, and $\mathrm{Pb}$, from macroelements allocated by $\mathrm{K}$. It is noteworthy that the emissions from industrial enterprises and soil dust are carried along with plumes from wildfires [50]. The effect of soil dust, emissions from the industrial enterprises, together with smoke emissions from wildfires was most manifested in the elemental composition of the aerosol near the delta of the Selenga River (No. 6) and the Boyarsk settlement (No. 7). With a change in the direction of wind currents at the final sampling site (No. 8), the elemental composition of the aerosol again showed an increase in the concentrations of almost all the elements.

The enrichment factors calculated according to the formula 1 relative to $\mathrm{Al}$ revealed a significant enrichment of the aerosol (K > 1000) with Be, B, Zn, Mo, U, Sn, As, W, Tl, Sb, Cd, Ag, and Se, elements of both lithophilic and anthropogenic origin. Factors in the range $100<\mathrm{K}<1000$ were determined for Ni, $\mathrm{Co}, \mathrm{Li}, \mathrm{Th}, \mathrm{Cu}$, and $\mathrm{Pb}$. High enrichment factors for the elements were determined during the passage of the RV at the sites 3-5, 7, and 8 (see Figure 7). At site 6, the most exposed to the smoke emission, as well as during the passage of the RV from Listvyanka to Buguldeika (site 2), the enrichment factors for the elements were lower.

Factor analysis was used to identify groups of elements correlating between themselves. The concentration of each element in an individual sample is considered a result of the joint impact of some sources (factors) that must be identified during analysis. In other words, such groups are formed from the elements that have significant loadings on the given factor. Factor loadings are calculated from the correlation matrix of the elements. To interpret the analysis results, the factors that add up to the maximum variance in this series of observations are selected in the aerosol (Table 8, Figure 8A). The first four factors explain $88 \%$ of the total variance of the variables. We determined that the soil in the region is the main source of the aerosol particles in the near-water atmosphere of the lake, but in each factor, there are additional sources of variability in the concentrations of the elements.

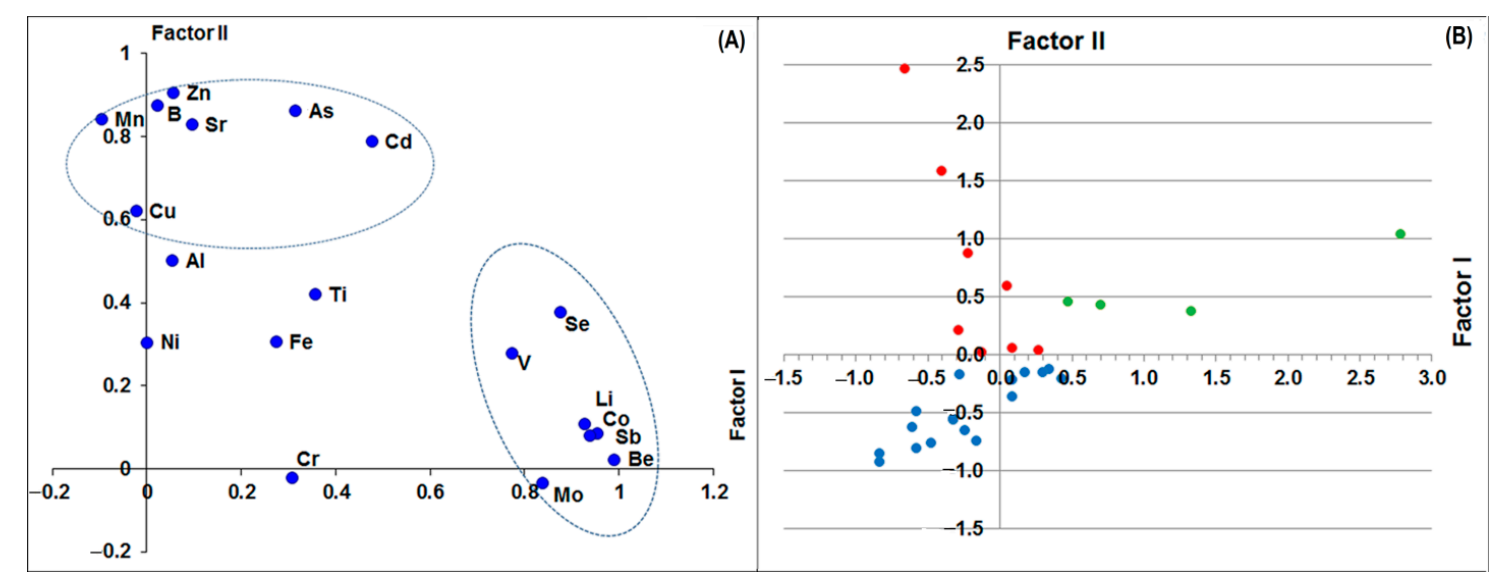

Figure 8. The distribution of the elements in the plane of the first two factors (A). The distribution of all collected aerosol samples in the plane of Factors I and II along the route of the RV «Akademik V.A. Koptyug» from 24 July to 4 August 2019 (B). 
Table 8. Factor loadings of the analyzed elements in the aerosol of the atmospheric near-water layer above Lake Baikal along the route of the RV «Akademik V.A. Koptyug» from 24 July to 4 August 2019 (The contribution of the factor to the total variance is indicated in the table below the names of the factors).

\begin{tabular}{|c|c|c|c|c|}
\hline \multirow{2}{*}{$\begin{array}{c}\text { Trace } \\
\text { Elements }\end{array}$} & Factor I, x & Factor II, y & Factor III, z & Factor IV, $t$ \\
\hline & $53.1 \%$ & $23.8 \%$ & $7.4 \%$ & $4.1 \%$ \\
\hline $\mathrm{Li}$ & 0.93 & 0.11 & 0.13 & 0.30 \\
\hline $\mathrm{Be}$ & 0.99 & 0.02 & 0.07 & 0.04 \\
\hline B & 0.02 & 0.88 & 0.05 & 0.01 \\
\hline $\mathrm{Al}$ & 0.05 & 0.50 & 0.29 & 0.78 \\
\hline $\mathrm{Ti}$ & 0.36 & 0.42 & 0.65 & 0.31 \\
\hline $\mathrm{V}$ & 0.77 & 0.28 & 0.08 & 0.53 \\
\hline $\mathrm{Cr}$ & 0.31 & -0.02 & 0.82 & 0.08 \\
\hline Mn & -0.10 & 0.84 & 0.29 & 0.26 \\
\hline $\mathrm{Fe}$ & 0.27 & 0.31 & 0.76 & 0.36 \\
\hline Co & 0.95 & 0.09 & 0.19 & 0.08 \\
\hline $\mathrm{Ni}$ & 0.00 & 0.31 & 0.23 & 0.72 \\
\hline $\mathrm{Cu}$ & -0.02 & 0.62 & 0.68 & 0.06 \\
\hline $\mathrm{Zn}$ & 0.06 & 0.91 & 0.13 & 0.32 \\
\hline As & 0.31 & 0.86 & -0.03 & 0.28 \\
\hline Se & 0.87 & 0.38 & -0.06 & 0.05 \\
\hline $\mathrm{Sr}$ & 0.09 & 0.83 & 0.41 & 0.14 \\
\hline Mo & 0.84 & -0.03 & 0.39 & 0.04 \\
\hline $\mathrm{Ag}$ & 0.99 & 0.10 & 0.07 & 0.04 \\
\hline $\mathrm{Cd}$ & 0.48 & 0.79 & 0.10 & 0.19 \\
\hline Sn & 0.96 & 0.06 & 0.25 & 0.02 \\
\hline $\mathrm{Sb}$ & 0.94 & 0.08 & 0.21 & 0.06 \\
\hline Ba & 0.30 & 0.29 & 0.75 & 0.19 \\
\hline W & 0.63 & 0.06 & 0.22 & -0.12 \\
\hline $\mathrm{Tl}$ & 0.99 & 0.10 & 0.07 & 0.04 \\
\hline $\mathrm{Pb}$ & 0.12 & 0.62 & 0.23 & 0.61 \\
\hline U & 0.99 & 0.04 & 0.11 & 0.02 \\
\hline
\end{tabular}

During our measurements, the invasion of the air masses from the northern areas of the Irkutsk Region and the Krasnoyarsk Territory, which contained smoke from wildfires, was an additional source of the formation of aerosol particles in the atmosphere above the lake (see Figures 2 and 3 ). This can be seen in Figure 8B where Factor I is responsible for the soil aerosol and reflects the contribution of the sources in the aerosol above Southern and Central Baikal. Factor II marked in red in Figure 8B shows the contribution of the emission from wildfires in the composition of the aerosol along the east coast of Lake Baikal.

Using Table 8, we can describe Factor II as the joint contribution of the group of the following elements in the formation of the elemental composition of aerosol particles: B, Mn, Zn, As, Sr, Cd, and $\mathrm{Pb}$. This allowed us to use them as markers during the entry of air masses from the areas prone to wildfires. Aerosol samples are rather well separated in elements in the plane of Factors I and II (see Figure 8B). Aerosol samples exposed to smoke emission from wildfires are marked in red; those collected near settlements (Baikalsk, Severobaikalsk, and Nizhneangarsk), are marked in green, and aerosol collected in clean areas are marked in blue. 
Similarly, we conducted a factor analysis for the ionic (soluble) part of aerosols (Table 9, Figure 9). Accumulation and dissipation of ions in the soluble part of aerosol occurs differently than in the solid part due to the constant watering of the particles in the air. Therefore, the distribution of samples on the plane of the first two factors has shown in this case (Figure 9B) that the first factor is the effect of the forest fire emissions (the incidence is marked in red), and only the second factor is responsible for the soil aerosol (marked in blue). Based on Table 9, we can predict that during the influx of smoke air masses, the soluble part of aerosols is enriched with the $\mathrm{NH}_{4}{ }^{+}, \mathrm{K}^{+}, \mathrm{SO}_{4}{ }^{2-}$, and $\mathrm{Li}^{+}$.

Table 9. Factor loads of the analyzed ions in the soluble part of aerosol in the near-water atmospheric layer of Lake Baikal along the route of the RV "Akademik V.A. Koptyug" from 24 July to 4 August 2019 (the contribution of the factor to the general dispersion is indicated under the name of the factor).

\begin{tabular}{cccc}
\hline \multirow{2}{*}{ Ions } & Factor $\mathbf{I}, \mathbf{x}$ & Factor II, $\mathbf{y}$ & Factor III, $\mathbf{z}$ \\
\cline { 2 - 4 } & $\mathbf{4 1 . 0 \%}$ & $\mathbf{2 2 . 1 \%}$ & $\mathbf{1 6 . 8} \%$ \\
\hline $\mathbf{N a}^{+}$ & -0.44 & 0.41 & -0.69 \\
\hline $\mathbf{N H}^{+}$ & 0.98 & 0.08 & 0.01 \\
\hline $\mathbf{K}^{+}$ & 0.91 & 0.17 & 0.05 \\
\hline $\mathbf{M g}^{2+}$ & 0.06 & 0.95 & 0.04 \\
\hline $\mathbf{C a}^{2+}$ & 0.20 & 0.90 & 0.01 \\
\hline $\mathbf{C l}^{-}$ & -0.03 & 0.34 & 0.71 \\
\hline $\mathbf{N O}_{3}{ }^{-}$ & 0.49 & 0.57 & -0.31 \\
\hline $\mathbf{S O}_{4}{ }^{+-}$ & $\mathbf{0 . 8 4}$ & 0.12 & -0.17 \\
\hline $\mathbf{L i}^{+}$ & $\mathbf{0 . 4 4}$ & 0.22 & -0.72 \\
\hline
\end{tabular}
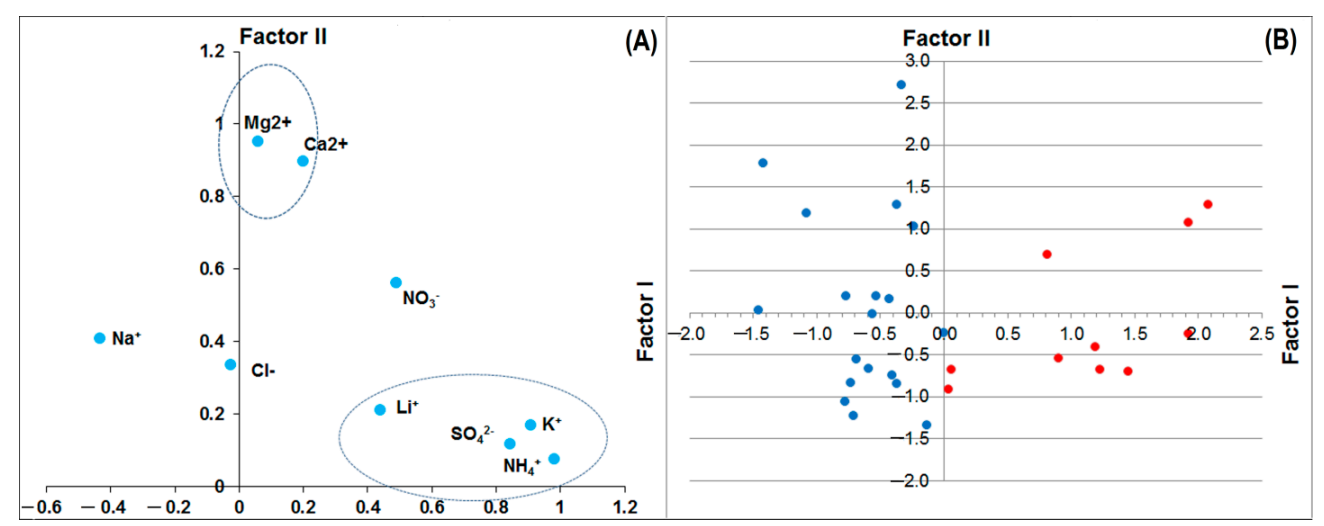

Figure 9. Ion distribution in the space of the first two factors (A). The distribution of all collected aerosol samples on the plane of the factors 1 and 2 along the route of RV "Akademik V.A. Koptyug" from 24 July to 4 August 2019 (B).

\section{Conclusions}

Based on the studies carried out from 24 July to 4 August 2019, involving the data on previous years, the impact was reviewed of both natural and anthropogenic factors on the state of physicochemical parameters of the near-water aerosol above Lake Baikal. Despite the constant influence of the anthropogenic factors of both local and regional scales, the atmosphere above most of Lake Baikal remains clean. However, in recent decades, due to climate change in Siberia, the number of wildfires have been increasing. The smoke from wildfires impenetrate the watershed area of Lake Baikal and its water areas and have affected significantly the physical properties and the chemical composition of the aerosol above the lake. The mass and number concentrations of submicron fractions in aerosol particles, as well as the concentrations of ions and the elements of polyaromatic compounds, increased. 
With the smoke emission in the summer of 2019, the natural background of the sum of ions in the aerosol above Lake Baikal, which is below $1.0 \mu \mathrm{g} / \mathrm{m}^{3}$, was on average more than six times higher. The concentrations of $\mathrm{NH}_{4}{ }^{+}, \mathrm{K}^{+}, \mathrm{NO}_{3}{ }^{-}$, and $\mathrm{SO}_{4}{ }^{2-}$ increased significantly in the aerosol composition.

Factor analysis revealed the association of elements ( $, \mathrm{Mn}, \mathrm{Zn}, \mathrm{As}, \mathrm{Sr}, \mathrm{Cd}$, and $\mathrm{Pb}$ ) whose elevated concentrations may indicate the influx of air masses from the areas prone to wildfires. We also determined that the composition of individual PAHs in the smoke aerosol from the nearby wildfires differed from the composition of PAHs that entered from the distant areas, which may serve as a tracer for different types of fires.

Despite the short duration of the impact of wildfires on the air basin of Lake Baikal, they contribute significantly to the change in the properties of the near-water atmosphere above the lake.

Author Contributions: Conceptualization L.G.; Organization of expeditionary measurements, T.K.; Expeditionary measurements, L.G., V.P., I.M., O.K., and P.R.; Physicochemical analysis of samples, L.G., O.K., N.O., I.M., and V.P.; Writing original draft L.G.; Review and editing, T.K. All authors have read and agreed to the published version of the manuscript.

Funding: This research was supported by the project of the Russian Science Foundation (RSF) No. 19-77-20058.

Acknowledgments: This study was supported by the project of the Russian Science Foundation (RSF) No. 19-77-20058 «Studies of the composition and spatiotemporal distribution of the aerosol-gas impurities in the Lake Baikal atmosphere». The investigations were carried out using the equipment of the center of shared facilities «Atmosphere», Institute of Atmospheric Optics Siberian Branch of the Russian Academy of Sciences.

Conflicts of Interest: The authors declare no conflict of interest.

\section{References}

1. Yue, X.-L.; Gao, Q.-X. Contributions of natural systems and human activity to greenhouse gasemissions. Adv. Clim. Chang. Res. 2018, 9, 243-252. [CrossRef]

2. World Fire Statistics. Available online: https://www.ctif.org/sites/default/files/2020-06/CTIF_Report25.pdf (accessed on 25 September 2020).

3. Anenberg, S.C.; Belova, A.; Brandt, J.; Fann, N.; Greco, S.; Guttikunda, S.; Heroux, M.-E.; Hurley, F.; Krzyzanowski, M.; Medina, S.; et al. Survey of Ambient Air Pollution Health Risk Assessment Tools. Risk Anal. 2016, 36, 1718-1736. [CrossRef] [PubMed]

4. Grennfelt, P.; Engleryd, A.; Forsius, M.; Hov, Ø.; Rodhe, H.; Cowling, E. Acid rain and air pollution: 50 years of progress in environmental science and policy. Ambio 2020, 49, 849-864. [CrossRef] [PubMed]

5. Karagulian, F.; Belis, C.A.; Dora, C.F.C.; Prüss-Ustün, A.M.; Bonjour, S.; Adair-Rohani, H.; Amann, M. Contributions to cities' ambient particulate matter (PM): A systematic review of local source contributions at global level. Atmos. Environ. 2015, 120, 475-483. [CrossRef]

6. Chaibou, A.A.S.; Ma, X.; Sha, T. Dust radiative forcing and its impact on surface energy budget over West Africa. Sci. Rep. 2020, 10, 12236. [CrossRef] [PubMed]

7. Katra, I.; Gross, A.; Swet, N.; Tanner, S.; Krasnov, H.; Angert, A. Substantial dust loss of bioavailable phosphorus from agricultural soils. Sci. Rep. 2016, 6, 24736. [CrossRef]

8. Tobias, A.; Karanasiou, A.; Amato, F.; Roqué, M.; Querol, X. Health effects of desert dust and sand storms: A systematic review and metaanalysis protocol. BMJ Open 2019, 9, 029876. [CrossRef]

9. Lee, E.-H.; Sohn, B.-J. Recent increasing trend in dust frequency over Mongolia and Inner Mongolia regions and its association with climate and surface condition change. Atmos. Environ. 2011, 45, 4611-4616. [CrossRef]

10. Jugder, D.; Shinoda, M.; Sugimoto, N.; Matsui, I.; Nishikawa, M.; Park, S.-U.; Chun, Y.-S.; Park, M.-S. Spatial and temporal variations of dust concentrations in the Gobi Desert of Mongolia. Glob. Planet. Chang. 2011, 78, 14-22. [CrossRef]

11. Middleton, N. Variability and Trends in Dust Storm Frequencyon Decadal Timescales: Climatic Drivers and Human Impacts. Geosciences 2019, 9, 261. [CrossRef]

12. Zhang, K.; Chai, F.; Zhang, R.; Xue, Z. Source, route and effect of Asian sand dust on environment and the oceans. Particuology 2010, 8, 319-324. [CrossRef] 
13. Baylon, P.; Jaffe, D.A.; de Gouw, J.; Warneke, C. Influence of Long-Range Transport of Siberian Biomass Burning at the Mt. Bachelor Observatory during the Spring of 2015. Aerosol Air Qual. Res. 2017, 17, 2751-2761. [CrossRef]

14. Flannigan, M.D.; Amiro, B.D.; Logan, K.A.; Stocks, B.J.; Wotton, B.M. Forest fires and climate change in the 21st century. Mitig. Adapt. Strateg. Glob. Chang. 2005, 11, 847-859. [CrossRef]

15. Zong, X.Z.; Tian, X.R.; Yin, Y.H. Impacts of Climate Change on Wildfires in Central Asia. Forests 2020, 11, 802. [CrossRef]

16. Vinogradova, A.A.; Smirnov, N.S.; Korotkov, V.N.; Romanovskaya, A.A. Forest fires in Siberia and the Far East: Emissions and atmospheric transport of black carbon to the Arctic. Atmos. Ocean. Opt. 2015, 28, 566-574. [CrossRef]

17. Evangeliou, N.; Balkanski, Y.; Hao, W.M.; Petkov, A.; Silverstein, R.P.; Corley, R.; Nordgren, B.L.; Urbanski, S.P.; Eckhardt, S.; Stohl, A.; et al. Wildfires in northern Eurasia affect the budget of black carbon in the Arctic-A 12-year retrospective synopsis (2002-2013). Atmos. Chem. Phys. 2016, 16, 7587-7604. [CrossRef]

18. Black, C.; Tesfaigzi, Y.; Basseina, J.A.; Miller, L.A. Wildfire smoke exposure and human health: Significant gaps in research for a growing public health issue. Environ. Toxicol. Pharmacol. 2017, 55, 186-195. [CrossRef]

19. Rincón-Riveros, J.M.; Rincón-Caro, M.A.; Sullivan, A.P.; Mendez-Espinosa, J.F.; Belalcazar, L.C.; Quirama Aguilar, M.; Morales Betancourt, R. Long-term brown carbon and smoke tracer observations in Bogotá, Colombia: Association with medium-range transport of biomass burning plumes. Atmos. Chem. Phys. 2020, 20, 7459-7472. [CrossRef]

20. Federal Forestry Agency. Available online: https://aviales.ru (accessed on 17 September 2020).

21. Greenpeace. Available online: https://greenpeace.ru/news (accessed on 17 September 2020).

22. Berkin, N.S.; Makarov, A.A.; Rusinek, O.T. Baikal Studies: Textbook; Publishing house of Irkutsk State University: Irkutsk, Russia, 2009; Volume 291, ISBN 978-5-9624-0355-7. (In Russian)

23. Obolkin, V.; Khodzher, T.; Sorokovikova, L.; Tomberg, I.; Netsvetaeva, O.; Golobokova, L. Effect of long-range transport of sulphur and nitrogen oxides from large coal power plants on acidification of river waters in the Baikal region, East Siberia. Int. J. Environ. Stud. 2016, 73, 452-461. [CrossRef]

24. Sinyukovich, V.N.; Chernyshov, M.S. Water regime of lake Baikal under conditions of climate change and anthropogenic influence. Quat. Int. 2019, 524, 93-101. [CrossRef]

25. Xu, G.; Gao, Y. Atmospheric trace elements in aerosols observed over the Southern Ocean and coastal East Antarctica. Polar Res. 2014, 33, 23973. [CrossRef]

26. Marinaite, I.I.; Molozhnikova, E.V.; Khodzher, T.V. PAHs transfer and intake to the water area of Lake Baikal during the summer forest fires in 2016. In Proceedings of the SPIE, 24th International Symposium on Atmospheric and Ocean Optics, Atmospheric Physics, Tomsk, Irkutsk, Russia, 13 December 2018; p. 10833. [CrossRef]

27. QA/SAC-Americas. Available online: http://qasac-americas.org (accessed on 12 April 2020).

28. Acid Deposition Monitoring Network in East Asia. Available online: http://www.eanet.asia (accessed on 12 October 2020).

29. ARL NOAA. Atmospheric Resource Laboratory NOAA. Available online: http://www.arl.noaa.gov (accessed on 11 October 2020).

30. Golobokova, L.P.; Filippova, U.G.; Marinaite, I.I.; Belozerova, O.Y.; Gorshkov, A.G.; Obolkin, V.A.; Potemkin, V.L.; Khodzher, T.V. Chemical composition of atmospheric aerosol above the Lake Baikal area. Atmos. Ocean. Opt. 2011, 24, 236-241. (In Russian)

31. Golobokova, L.P.; Khodzher, T.V.; Obolkin, V.A.; Potemkin, V.L.; Khuriganova, O.I.; Onischuk, N.A. Aerosol in the atmosphere of the Baikal region: History and contemporary researches. Limnol. Freshw. Biol. 2018, 1, 49-57. [CrossRef]

32. Khodzher, T.V.; Zhamsueva, G.S.; Zayakhanov, A.S.; Dementeva, A.L.; Tsydypov, V.V.; Balin, Y.S.; Penner, I.E.; Kokhanenko, G.P.; Nasonov, S.V.; Klemasheva, M.G.; et al. Ship-Based Studies of Aerosol-Gas Admixtures over Lake Baikal Basin in Summer 2018. Atmos. Ocean. Opt. 2019, 32, 434-441. (In Russian) [CrossRef]

33. State Scientific Center of the Russian Federation the Arctic and Antarctic Research Institute. Available online: http://www.aari.ru (accessed on 11 September 2020).

34. Kozlov, V.S.; Yausheva, E.P.; Terpugova, S.A.; Panchenko, M.V.; Chernov, D.G.; Shmargunov, V.P. Optical-microphysical proper ties of smoke haze from Siberian forest fires in summer 2012. Int. J. Remote Sens. 2014, 35, 5722-5741. [CrossRef] 
35. Federal State Budgetary Institution. «Irkutsk Department for Hydrometeorology and Environmental Monitoring». Available online: https://www.irmeteo.ru (accessed on 1 November 2020).

36. Obolkin, V.A.; Shamansky, Y.V.; Khodzher, T.V.; Falits, A.V. Mesoscale processes of atmospheric pollution transfer in the area of South Baikal. Oceanol. Res. 2019, 47, 104-113. [CrossRef]

37. Van Malderen, H.; Van Grieken, R.; Khodzher, T.V.; Obolkin, V.L.; Potemkin, V.L. Composition of individual aerosol particles above Lake Baikal, Siberia. Atmos. Environ. 1996, 30, 1453-1465. [CrossRef]

38. Rudnick, R.L.; Gao, S. Composition of the continental crust. In Treatise on Geochemistry; Holland, H.D., Turekian, K.K., Eds.; Elsevier: Amsterdam, The Netherlands, 2003; Volume 3, pp. 1-64. [CrossRef]

39. Reid, J.; Koppmann, R.; Eck, T.; Eleuterio, D. A review of biomass burning emissions. Part 2: Intensive physical properties of biomass burning particles. Atmos. Chem. Phys. 2005, 5, 799-825. [CrossRef]

40. Urbanski, S.P.; Hao, W.M.; Baker, S. Chemical Composition of Wildland Fire Emissions. Dev. Environ. Sci. 2009, 8, 79-107. [CrossRef]

41. Yli-Tuomi, T.; Venditte, L.; Hopke, P.K.; Basunia, M.S.; Landsberger, S.; Viisanen, Y.; Paatero, J. Composition of the Finnish Arctic aerosol: Collection and analysis of historic filter samples. Atmos. Environ. 2003, 37, 2355-2364. [CrossRef]

42. Grachev, M.A. On Recent State of Ecological System of Lake Baikal; Publishing House of the Siberian Branch of the Russian Academy of Sciences: Novosibirsk, Russia, 2002; Volume 156, ISBN 5-7692-0481-8. (In Russian)

43. Simoneit, B. A review of biomarker compounds as source indicators and tracers for air pollution. Environ. Sci. Pollut. Res. 1999, 6, 159-169. [CrossRef] [PubMed]

44. Schauer, J.; Kleeman, M.; Cass, G.; Simoneit, B. Measurement of emissions from air pollution sources. 3. C1-C29 Organic compounds from fireplace combustion of wood. Environ. Sci. Technol. 2001, 35, 1716-1728. [CrossRef] [PubMed]

45. Srogi, K. Monitoring of environmental exposure to polycyclic aromatic hydrocarbons: A review. Environ. Chem. Lett. 2007, 5, 169-195. [CrossRef] [PubMed]

46. Ravindra, K.; Sothi, R.; Van Grieken, R. Atmospheric polycyclic aromatic hydrocarbons: Source attribution, emission factors and regulation. Atmos. Environ. 2008, 42, 2895-2921. [CrossRef]

47. Tobiszewski, M.; Namiesnik, J. PAH diagnostic ratios for the identification of pollution emission sources. Environ. Pollut. 2012, 162, 110-119. [CrossRef] [PubMed]

48. Masclet, P.; Hoyau, V.; Jaffrezo, J.L.; Cachier, H. Polycyclic aromatic hydrocarbon deposition on the ice sheet of Greenland. Part I: Superficial snow. Atmos. Environ. 2000, 34, 3195-3207. [CrossRef]

49. Shcherbov, B.L.; Zhurkova, I.S. Forest fires as an important factor of scattering and concentration of chemical elements in Siberia. Geol. Miner. Resour. Sib. 2014, S3-2, 37-40. (In Russian)

50. Schlosser, J.S.; Braun, R.A.; Bradley, T.; Dadashazar, H.; MacDonald, A.B.; Aldhaif, A.A.; Aghdam, M.A.; Mardi, A.H.; Xian, P.; Sorooshian, A. Analysis of aerosol composition data for western United States wildfires between 2005 and 2015: Dust emissions, chloride depletion, and most enhanced aerosol constituents. J. Geophys. Res. Atmos. 2017, 122, 8951-8966. [CrossRef]

Publisher's Note: MDPI stays neutral with regard to jurisdictional claims in published maps and institutional affiliations.

(C) 2020 by the authors. Licensee MDPI, Basel, Switzerland. This article is an open access article distributed under the terms and conditions of the Creative Commons Attribution (CC BY) license (http://creativecommons.org/licenses/by/4.0/). 